\title{
Personal Entrepreneurial Attributes and Intentions to Start Business: The Moderating Role of Culture
}

\author{
Syed Danish Haider Naqvi (Corresponding author) \\ Karachi University Business School (KUBS), University of Karachi. \\ KU Circular Road, University of Karachi, Karachi, Pakistan. \\ E-mail: syeddanishhaider5@gmail.com \\ Dr. Danish Ahmed Siddiqui \\ Associate Professor, Karachi University Business School \\ Karachi University Business School (KUBS), University of Karachi. \\ KU Circular Road, University of Karachi, Karachi, Pakistan. \\ E-mail: daanish79@ hotmail.com
}

Received: Nov. 13, 2019 Accepted: Dec. 6, 2019 Online published: Dec. 12, 2019

doi:10.5296/ijhrs.v10i1.15817～URL: https://doi.org/10.5296/ijhrs.v10i1.15817

\begin{abstract}
Culture influence the entrepreneurial intentions, which make a contribution to entrepreneurial evolution. This study investigates that whether (Hofstede, Dimensionalizing Cultures: The Hofstede Model in Context, 2001) cultural dimensions has a moderating role in converting Personal Entrepreneurial Attributes into their Intention to Start a Business. To measure these attributes, we applied bounded multidimensional model of social entrepreneurship as proposed by (Weerawardena \& Mort, 2006) and applied by (Richter, et al., 2016). The effect of three Entrepreneurial Attributes namely risk taking, innovativeness and pro-activeness along with other demographic variables were tested against entrepreneurial intensions (EI). Their effect was moderated by five cultural dimensions namely Masculinity, Power Distance, Long-Term Orientation, Collectivism, and Uncertainty Avoidance. Data of 272 respondents from Pakistan was collected using close ended questionnaire and was analysed using Confirmatory factor analysis and structured equation modelling by means of path model which specifies various constructs of this study. The results suggested that risk taking and pro-activeness had a positive and significant effect on EI, whereas innovativeness doesn't seem to effect EI. This imply that risk takers and proactive individuals are more inclined
\end{abstract}


towards entrepreneurship than innovators. With regards to cultural dimensions, Masculinity, Power Distance, and Collectivism seems to negatively affect EI, whereas Long-Term Orientation, and Uncertainty Avoidance seems to effect positively. Interestingly, Collectivism and Masculinity have positive and significant complementarities with innovativeness, whereas Uncertainty Avoidance have negative and significant effect. This means innovativeness does seem to effect EI in collective and masculine culture. This also suggested that innovators would be more inclined in converting their ideas into workable projects in collective decision making and hierarchical cultural settings. Conversely, Uncertainty Avoidance, seem to restrict Entrepreneurial aspirations in innovators. Cultural variable doesn't seem to have a significant moderation effect with regards to risk taking, except of Long Term Orientation, that have significant negative complementarities. Surprisingly, Masculinity, and Collectivism had and significant negative moderating effect with pro-activeness and EI, whereas Long Term Orientation and Uncertainty Avoidance have a significant positive interaction. This suggested that hierarchical culture deter proactive people in fulfilling their EI, at the same time, encourage innovators. With regards to demographics, male seems to have more EI, whereas the coefficient of education and age found that advanced education and experienced individuals believes in development, increasingly slanted toward entrepreneurship. Frames of mind to completing the expectations are poor in entrepreneurship.

Keywords: cultural dimensions, moderating effect, pro-activeness, innovativeness, risk taking, entrepreneurial intentions, Pakistan

\section{Introduction}

Any individual who begins a business with another thought or includes any sort of significant worth in officially existing thought or thought is considered as a business visionary. They consider as a maker and daring individual who are capable to get change their environment. They do it with the assistance of innovation and prepared their association's worker adequately and afterward give a chance to their organization to get the greatest benefit (Sajjad, Shafi, \& Dad, 2012). Numerous academic studies have observed the effects of culture on entrepreneurial movement.

Entrepreneurial motivation is vital in translating entrepreneurial intention into action (Malebana, 2014). Essentially, the most featured components are instruction and work on with respect to the business behind the thought and quest for entrepreneurial intention $(\mathrm{Wu}$, Wang, Zheng, \& Wu, 2019). Entrepreneurial intention is formed by personal and environmental aspects. The reputation of entrepreneurship as a provider to job formation, innovation and economic development is widely acknowledged (Sesen, 2013).

Attitude to menace is the strongest predictor towards entrepreneurial intention (Bell, 2018). Business visionaries or entrepreneurs are considered as more daring individual as a contrast with different people according to the meaning of enterprise and ordinary reflection. Entrepreneurial intention can be considered as a reflection of the state of mind of an individual which prompts them towards taking up self-employment rather than being employed (Karimi, et al., 2016). 
Different business components impact entrepreneurial intention like better alluring quality, creative experience and capacity to accomplish objective, yet every nation has its very own way of life so it might vary starting with one nation then onto the next nation, we trust that inside country culture vacillates, investigators are yet misty to recognize the general impacts of culture in business visionary objective (Mitchell, et al., 2002). Every nation has its very own way of life, its qualities, standards and convictions that influences the enterprising expectation, at certain stages the way of life assumes an essential job in basic leadership.

\subsection{Background of the Study}

(Miller, The correlates of entrepreneurship in three types of firms, 1983) first hypothesised the entrepreneurial intention construct and later refined by (Covin \& Slevin, 1989). Anybody is animated to make thoughts and go for broke in an entrepreneurial society since it is thinking about as a situation that upgrades people's capacities to accomplish their objectives in a most fitting manner. Where the fields of entrepreneurship are apprehensive, this is without a doubt that as a department of business, has essential roots in various older and extra hooked up fields and with accurate reasons. Individuals drive into business for themselves for several motives. Some of them want to switch from corporate environment towards autonomy. Others wish to pursue a particular vision.

The culture is a consideration of the values the entrepreneur conveys into the business. Culture plays a vital role for entrepreneurial venture. Culture affect the entrepreneurial manners, which make a contribution to entrepreneurial evolution. The social setting in which the humans grow, contours their simple beliefs, values and norms. There are positive cultural practices and standards in each and every society which impact the movements of personages.

Entrepreneurs do not purely increase to their very own non-public affluences; in addition, they enhance the lives of millions of individuals through the innovative products and offerings they bring to the market. In latest years, the attraction of entrepreneurship has enlarged, with the result that greater people than ever earlier than are selecting this endeavour as a career. The field of entrepreneurship acknowledges that each the micro point of view (which focuses on the behaviour and ideas of individuals) and the macro perspective (which focuses especially on environmental factors) are vital for obtaining a full grasp of the entrepreneurial process.

\subsection{Problem Statement}

Entrepreneurial intention and Personal Entrepreneurial Attributes like innovativeness, risk-taking and pro-activeness can be profoundly alienated between the aspects of procedure and effect, the sub-dimensions and the aspects of procedure and outcome are also discussed to vary independently of each other (Linton, Innovativeness, risk-taking, and proactiveness in startups: a case study and conceptual development, 2019). Numerous intellectual studies have examined the impact of culture on entrepreneurial intention. (Thurik \& Dejardin, 2011) clarifies that adjustment in culture from nation to nation affect individual to individual in their method for carrying on, together with the choice to develop to act naturally utilized 
rather than a worker.

Individuals have properties yet not have EI because of scared of disappointment, similar to they think in the event that they will neglect to accomplish their objective, there will be no chance at that point. A few people feel that it is too old to even consider starting from scratch. Some accepts that they are excessively youthful, without enough experience. They feel under-taught or over-instructed or hanging tight for better planning or an occasion. Having no cash to contribute, being shy of money is additionally the fundamental purpose behind individuals who don't centre toward EI. A few people an excessively low in certainty, not having the guts to manage the individuals in various circumstances. Some of them don't have the foggiest idea how to begin the business and else having no clue what business to begin. Being uncertain about entrepreneurship, as might be employment is a superior alternative than business, keep away from to go out on a limb, considering employment is a superior fit.

Cultural values assume its job in entrepreneurship improvement. According to (Tukur \& Adam, 2017) culture straightforwardly or by implication impacts EI on the grounds that it alludes to more than unimportant ethnicity, however a group of stars of shared significance, qualities, customs and methods of collaboration with other like how individuals carry on and live with other and keep their association with others. Business visionaries reflects prevailing estimations of their national culture. It relies upon nation to nation, a few societies are increasingly strong and gives reasonable opportunity to everybody.

We can say that societies are not impeccable, they have a few provisos in it when it will clarify the term entrepreneurship. Individuals need to comprehend what to do and what not to do in restrictive societies. Along these lines, there is no 'best' culture of business enterprise. Also, on the opposite side, countries that have individualists should not fulfil, even they have more business visionaries. In addition, social orders of collectivist are useful for entrepreneurs too. As indicated by research in Japan or Sweden, social qualities help them in finding new chances on the off chance that they get increasingly people to begin new organizations. Setup of society is as per their thoughts that lift their self-awareness. They generally persuade their business visionaries to go out on a limb and dependably consider development. Further, there are additionally some social factors that don't enable the business person to think imaginatively and simply pursue the past age standards and guidelines and indiscriminately pursue the principles they made for their benefit. Essentially, they accomplish more endeavours for the entrepreneurship (Wennberg, Pathak, \& Autio, 2013).

\subsection{Gap Analysis}

(Maritz \& Donovan, 2015) investigates the connection among business and development instruction and preparing programs. The gap in that examination is depiction of entrepreneurship, the general theoretical based drew closer can be find more, additionally give a training based view. (Kerr, Kerr, \& Xu, 2017) audit the broad writing on character qualities of entrepreneurs, by embracing the standard like Big-5 model. Likewise consider hazard frames of mind and goals of entrepreneurs, talking about the passage and exit to entrepreneurship. Gap in this examination that how innovative character interfaces with firms' exhibition. 
(Danish, Asghar, Ahmad, \& Ali, 2019) thinks about entrepreneurial culture as a region of examination, they portrayed that culture as power, abilities and qualities. They look at the impact of receptiveness to change on enterprising society, by gathering information from capital city of Province Punjab, Pakistan. Investigated that self-efficacy and openness to change have positive effect on innovative culture. Limitations of this research is longitudinal methodology and subjective strategies. (Muhammad, Ullah, \& Warren, 2016) utilized institutional viewpoint to look at different weights on business people in a contention situation. They embrace subjective methodology by interviewing 16 distinct firms and discover various methodologies to manage the contention and setting up authenticity. (Ahmed, Chandran, \& Klobas, 2017)have inquired about whether the entrepreneurship education program can advance EI and conduct, with control gathering of MBA in Pakistan. They discovered that MBAs have more EI than EEP understudies, in spite of the fact that not discover any distinction in dispositions. Limitations for this exploration is that there is no longitudinal examination, cross sectional plan gives no data in regards to expectations and predecessors.

(Ndubisi \& Iftikhar, 2012) investigate the connection between entrepreneurship, innovations and quality performance by considering about two different groups. Discovered that there is a noteworthy direct connection between all factors. They additionally included three components of entrepreneurship with their examination to be specific pro-activeness, risk-taking and autonomy. Limitations about the examination is that sample is constrained to support SMEs in Pakistan. Moreover, culture as indicated by the nation isn't considered in their investigation. In addition, they just looked at just IT sector.

(Richter, et al., 2016) inspecting the impacts of culture on intentions and behaviours inside association. They used information from 10 different nations and recognize six cultural archetypes. Discovered that culture do impact EI and furthermore suggested that approach of cultural archetype is more helpful for breaking down multifaceted impacts than conventional approaches. However, they embrace Hofstede model but excluded 6th element of culture, indulgence versus restraint. Likewise, they cover the chose set of individuals. Nations that are a part of African, Arab and the Nordic are not considered. Just take the information from business understudies is likewise a constraint for this investigation. Group testing may constrain their information, as shortcomings to distinguishing the right number of bunches.

This investigation will cover the previously mentioned gaps; Concentrate more on innovativeness, risk-taking and pro-activeness by associating it in our examination as a variable and also considering role of cultural dimension like masculinity, power distance, uncertainty avoidance, long-term orientation and collectivism. Additionally, include diverse age groups and professions in our examination by considering about the lifestyle of a people. Additionally, will cover Pakistani cultural effects for EI in detail.

Pakistan has not been considered before with respect to investigate the effect of cultural elements of Hofstede model on entrepreneurship by considering three business people's measurements; innovativeness, risk taking and pro-activeness. 


\subsection{Objectives of the Study}

(Richter, et al., 2016) examined the culture of 10 different countries and furthermore distinguished six cultural archetypes that those nations pursue. For this, they completed four stages of examination through their model by embracing the model without cultural dimensions and later on demonstrated the effect of cultural dimensions.

We in our exploration study include one more country (Pakistan) in it and through this model, endeavour to discover the directing impact of cultural dimensions on entrepreneurial intention. In this conceptual framework, we examine the effect of three independent factors for example risk taking, pro-activeness and innovativeness on entrepreneurial intention and utilize Hofstede's cultural dimensions for example collectivism, uncertainty avoidance, power distance, long term orientation and masculinity as a moderating variable

We consider five cultural dimensions to decide social originals by utilizing single social measurements or a country. We don't contend that a cultural archetype is basically relates to a nation. Each nation has its distinctive culture that is the reason we will consider just a single nation in general and take information from various age groups and professions. We like to add to the social administration writing, rather than centring just a single social measurement, we will talk about five distinctive cultural dimensions. Our methodology will bolster the past inquires about (Dorfman \& Howell, 1988) that expounds the effect of individualism/collectivism, power distance social qualities as evaluated with (Aycan, Mendonca, Kanungo, \& Yu, 2000), other cultural dimensions clarified by (Earley, Erez, \& Bhagat, 1995). Moreover, objectives that we need to discover with this investigation are as per the following:

- To identify the moderating effects of Hofstede's Cultural Dimensions along with pro-activeness, risk-taking and innovativeness on Entrepreneurial Intention.

- To identify the impact of innovativeness on Entrepreneurial Intention.

- To identify the impact of risk-taking on Entrepreneurial Intention.

- To identify the impact of pro-activeness on Entrepreneurial Intention.

\subsection{Research Question}

- How Entrepreneurial intention is affected by different cultural dimensions?

- What is the relationship between innovativeness and EI, and what will be the impact of innovativeness on EI?

- What is the relationship between risk-taking and EI, and what will be the impact of risk-taking on EI?

- What is the relationship between pro-activeness and EI, and what will be the impact of pro-activeness on EI? 


\subsection{Significance of the Study}

We ought to do this exploration to discover the reasons and the holding between Pakistani Culture and Entrepreneurship by breaking down various practices and circumstances. It will tell us the effect of culture on entrepreneurial intention. Individuals will have a thought with respect to the expert pro-activeness, risk-taking and innovativeness of people. It encourages individuals to comprehend the connection among culture and entrepreneurship in Pakistan.

The decisions of this investigation will redound to the effect of the cultural dimension on entrepreneurial approach which embraces innovation, risk-taking and pro-activeness. Through this research, we get to know about the thinking patterns of people who belong to different fields. The goal of this study is to expose the impact of countrywide (Pakistan) way of life on entrepreneurship. This study will help us to know the factors that motivate an individual to start the business, either it may be small or big. Empirical analyses of model of entrepreneurial intention are associated with culture, so this study will also support to recognize the role of culture.

In current years, the area has made fast development towards the intention of appreciation entrepreneurship as a process, and that this progress, in turn, has yielded vital implications for supporting entrepreneurs in their struggles to form new ventures. This study will provide a new approach to evaluate and term cultural dimensions away from the common statistical measures. Though the involved three personality traits (innovativeness, risk-taking, and pro-activeness) signify a commonly believed set of imperative predictors of intention, which will reconfirm in this study.

In this study, (Hofstede, Dimensionalizing Cultures: The Hofstede Model in Context, 2001) five cultural dimensions has been discussed. (Taras, L.Kirkman, \& Steel, 2010) also identified in their literature that those Hofstede five cultural dimensions are the most fundamental dimensions of culture. For the reason of this illustrative study, entrepreneurial intention model has been considered that consists of risk taking, innovativeness and pro-activeness as direct antecedents. The Hofstede's five cultural dimensions are labelled:

\section{Cultural Relation}

\section{Dimensions}

Masculinity related to the unit of expressive jobs among ladies and men.

Power identified with the exceptional answers for the essential issue of human Distance disparity.

Long-Term identified with the inclination of point of convergence for individuals' Orientation endeavours: the future or the current and past.

Collectivism related to the joining of characters into essential gatherings.

Uncertainty identified with the phase of worry in a general public despite an Avoidance unidentified imminent. 
This research will furnish us the instruction about the perspective, an entrepreneur need to be aware of and understand earlier than starting the business, like either the culture is going to have an effect on their entrepreneurial mind-set or not.

\section{Review of Literature}

(Subotic, Maric, Mitrovic, \& Mesko, 2018) examined about innovativeness, the objective for this paper is to discover the difference between behaviour that is innovative and adaptive. This exploration has been directed by Kirton Adaption-Innovation(KAI) model and the likewise discover that how these factors sway entrepreneurial potential dimensions. They gathered the information from a sample of 1008 university understudies from Serbia, Bosnia and Herzegovina. Result demonstrates that youthful understudies have more development and they are more probable towards business enterprise. Additionally, found that there are contrasts among understudies with respect to the nation of initial point.

(Prasad, Ehrhardt, Liu, \& Tiwari, 2015) explored whether older or more youthful business visionaries are in better position to accomplish performance outcomes. To lead look into the connected Galenson Fs theory of innovativeness and discover the relationship between entrepreneur age and venture performance through the sample of 1182 early business visionaries. Discovered that there is a negative connection between entrepreneur age and performance for "innovative" ventures. In addition, between entrepreneur age and performance for "imitative" venture, they found no relation.

(Sandberg, Hurmerinta, \& Zettinig, 2013) target to do this exploration is to explain the ideas of innovativeness and entrepreneurial people by doing the investigation of personality attributes. By visiting more than 100 organizations they accumulate the sample through theme interviews and press cuttings from Turku, Finland. Discovered that the worry of an individual isn't the assent of group of actors.

(Zeffane, 2015) included the variable of risk taking and inclination to trust in past researches for gender contrasts in entrepreneurial exercises. They discovered that gender contrasts powers a person to go for broke and become entrepreneur, while additionally quote some research that deny any huge contrasts. Additionally, they found that women are very little associated with entrepreneurial exercises as contrast with men.

(Marina, Paul, Harry, \& Vladimir, 2013) goal is to investigate the linkage between entrepreneurship specific education (ESE) investments, alertness and risk-taking resource collection. They assemble the information from 189 understudies of three universities in the Ukraine. They investigated that understudies who have a place with ESE got higher force of entrepreneurial mind-set. However, risk-taking is the factor that impacts ESE understudies, similar to ESE understudies who go out on a limb are increasingly arranged to higher entrepreneurial mind-set.

(Humbert \& Brindley, 2015) investigated the myth of risk-averseness among women business people and need to do examination with respect to risk through gender. They interviewed ten Irish women business visionaries and accumulate data about their entrepreneurial encounters. They found that risk do have a place with the gender idea that ought to be 
enlarged and as per the financial condition

(Wong, 2012) investigated about the immediate and aberrant effect of pro-activeness, risk taking and innovativeness on entrepreneurial orientation. Information was gathered from 244 electronics manufacturers in China. They found that drivers of predecessors of new product success NPS are measurements of EO which incorporates pro-activeness, risk taking and innovativeness. Moreover, found that pro-activeness and innovativeness moderate the connection between risk taking and product advantage.

(Dickel, 2017) investigated new pursuits environmental performance which is affected by technological protect ability and pro-activeness. In this investigation he applies regression examination by gathering the information from 150 clean innovation adventures. They found that environmental performance can be expanded through protect ability and proactive conduct.

Relationship among the age, education and entrepreneurial orientation which incorporates pro-activeness, risk taking and innovativeness, analysed by the (Kropp, Lindsay, \& Shoham, 2008) The data from 539 people was taken from various firms of South African. They found that ingenuity is certainly not a decent factor to begin a business, though pro-activeness and risk taking are sure parts of EO.

(Linton, Innovativeness, risk-taking and pro-activeness in startups: a case study and conceptual development, 2019) analyzes that the risk-taking, pro-activeness and innovativeness the sub-dimensions of Entrepreneurial orientation (EO) may connect with one another through the parts of procedure and result. Information for a long time was gathered on which subjective research had been directed. The outcomes demonstrate that between the attributes of the procedure and result the sub-measurements of EO can be isolated effectively as they can work autonomously of one another. It is prescribed that more research ought to be done later on for a superior comprehension of kinds of various business enterprise.

(Anlesinya, Adepoju, \& Richter, 2019) objective is to discover the cultural orientations and desire of Ghanaian women toward entrepreneurship. 190 females were studied who belong to Ghana, Africa by applying hierarchical regression examination. Cultural measurements power distance, long term orientation, masculinity, collectivism and uncertainty avoidance have been examined, and result demonstrates that collectivism and masculinity does not impact expectation to begin another business. This examination likewise found that cultural measurements are not directed by seen emotionally supportive network.

(Crespo, 2017) aim to discover the entrepreneurial movement EA that is affected by the national social measurements, either higher or lower. By utilizing the information from Global Entrepreneurship Monitor and furthermore gathering the information from 77 nations through Hofstede Centre. They found that national culture joins with different degrees of monetary improvement, at that point entrepreneurial movement would be higher.

For understanding that how culture affects entrepreneurs' propensity, (Brieger \& Clercq, 2019) collected a sample of 12685 business visionaries from 35 distinct nations using Global Entrepreneurship Monitor (GEM). This investigation results found that culture pressurize 
entrepreneurs that how they dispense their assets towards social value creation.

(Obeidat, et al., 2016) examines culture along with the relationship among strategic human resource management and national culture. Precisely, national culture, organization culture, culture and strategic human resource management was reviewed along with the cultural dimensions of Hofstede's i.e. Power Distance, Masculinity, Uncertainty avoidance /Femininity, long versus short-term orientation, Individualism/ Collectivism.

(Richter, et al., 2016) examines that inside the associations' practices and aims are influenced by culture alongside certain distinctions related to cross-culture. An overview was led to the examination. Partial Least Square equation model through Smart PLS were applied. The outcomes demonstrate that conventional approached are less influenced than the cultural model which is increasingly proper for cross-cultural effects.

(Smith, Sirdeshmukh, \& Combs, 2016) analyzes the associations between gender, creativity and entrepreneurial intensions. The two-study design has been conducted by using (Hayes, 2013) process of macro. The outcomes demonstrate that creativity significantly affects entrepreneurial intention while gender has a circuitous effect. The outcome likewise demonstrates that gender and creativity are interrelated in such a way, that entrepreneurial and creativity demonstrates a more grounded association with one another.

(Rahim, Ismail, Thurasamy, \& Rahman, 2018) analyzes the Entrepreneurial Intention with another perspective and affiliation which leads towards consistency.

(Sahin, Karadag, \& Tuncer, 2019) researches that to start-up a new business couple of attributes are to be remembered as an individual dimension that directs entrepreneurial aim. Survey data was utilized on which fluffy set qualitative comparative analysis(fsQCA) was connected. The outcomes demonstrate that through various developments of individual characteristics and entrepreneurial self-efficacy (ESE) propelled dimension of innovative aim can be seen.

Above examined papers talked about the three measurements on entrepreneurship; innovativeness, risk taking and pro-activeness. Additionally, discussed about the connection among culture and entrepreneurship. Cultural measurements that have been talked about in above papers has a place with Hofstede model. Age, gender and education are additionally the fundamental factors that impacts entrepreneurial mindset, these variable have been talked about also.

\section{Theoretical Framework}

\subsection{Explanation of the Concepts}

\section{Risk Taking}

Risk taking is considered as an important construct of entrepreneur, it includes financial risk, job risk, social risk and mental risk. Most of entrepreneur's finances are done by savings and personal possessions and if they fail, they are at loss. They take risks of failure. Financial risk is a big risk that an entrepreneur takes to start his business keeping in mind the future losses 
that he can bear. This is the biggest concern of managers who want to have a secure organizational job with good remunerations. In general, the entrepreneurs wouldn't consider every kind of risk, but they consider rational and risks. It means the entrepreneurs, not only follow the ideas as working scenario, but also consider the current risks of these ideas. The starting of entrepreneurial job needs an activeness and is time consuming. He may confront some social and family damages that can occur because of her or his absence in the home and its effects on his / her family. The risk of mental tensions, stress, anxiety and the other mental factors have many negative impacts because of the entrepreneurial activities. This time means the time which is the introduction of the later successes - is a part of entrepreneurship. Profitability, as one of the signs in entrepreneurial individuals and organizations, is achieved by high return. In the emulative world, the high return requires high risk.

\section{Pro-activeness}

Whereas the construct pro-activeness is defined in (Merriam-Webster, 1991) as "acting in anticipation of future problems, needs, or changes." It is active to influence and lead the future rather than waiting to be influenced by it; it involves take advantage of opportunities and accepting the responsibility of failure (Kuratko, 2007). It is being able to anticipate future problems, needs for change, and improvement (Kremer, Zappe, \& Sarah, 2006). Pro-activeness was used to represent a firm that was the quickest to innovate and first to introduce new products or services (Miller, The Emergence of the Entrepreneurial Orientation (EO) Construct, 1983).

\section{Innovativeness}

(Tredgold, 2018) looking over ninety-three percent of officials at various levels, innovativeness is said to be the basic piece of organization's long haul achievement. It demonstrates that a pioneer or a business person ought to be innovative, as innovativeness has an exceptionally solid association with entrepreneurship. For the most part the fruitful business visionaries know the models that ought to be adjusted in their business, that is innovativeness.

\section{Long Term Orientation}

Long term orientation (LTO) alludes toward moderate outcomes. Principle work and qualities in LTO incorporates self-control, learning, genuineness, adaption and responsibility. To put it plainly, individuals who pursue LTO values frames of mind and activities that influence what's to come.

\section{Masculinity}

Individuals esteems achievement, cash and material belongings. A portion of the people move towards these things like masculine while there is an idea that feminine societies place more an incentive on connections and personal satisfaction.

\section{Power Distance}

Power distance (PD) is that element of a culture that mirrors how much chain of command 


\section{Macrothink}

International Journal of Human Resource Studies

ISSN 2162-3058

2020, Vol. 10, No. 1

and inconsistent circulation of power are acknowledged. Power distance alludes to the degree of imbalances, tells about the bosses and subordinates. It centers around the uniformity or imbalance, between individuals in the nation's general public. PD societies bring together or decentralize the power into a wide range of associations and employment positions. To put it plainly, the measurement manages the reality pretty much all people in social orders are not rise to. While, these disparities among us is communicated by the disposition of the way of life.

\section{Uncertainty Avoidance}

Workers don't search for a momentary goal once they get connected to the association. Then again, a few associations have representatives who are increasingly stressed over their position and picture. A few associations' accentuations are on long haul association with the representatives. In such associations, individuals endeavour to accomplish shared objectives and to satisfy the desires for the administration. At the point when representatives realize how to manage unanticipated or sudden situations, it is known as the Uncertainty Avoidance Index.

\section{Collectivism}

People function as a group who are having regular interests and objectives. In such a situation the workers bond with one another and share a decent relationship among themselves. Associations will pursue various approaches if their male representatives are more overwhelming than female workers when contrasted with associations where females have a noteworthy job in the basic leadership procedure of the association. A few associations put stock in enlisting group pioneers who are in charge of their separate groups. The group chiefs give requests and bits of exhortation to their colleagues which they should pursue and work as needs be. The executives give equivalent treatment to each representative and they have to possess their every activity and choice. 


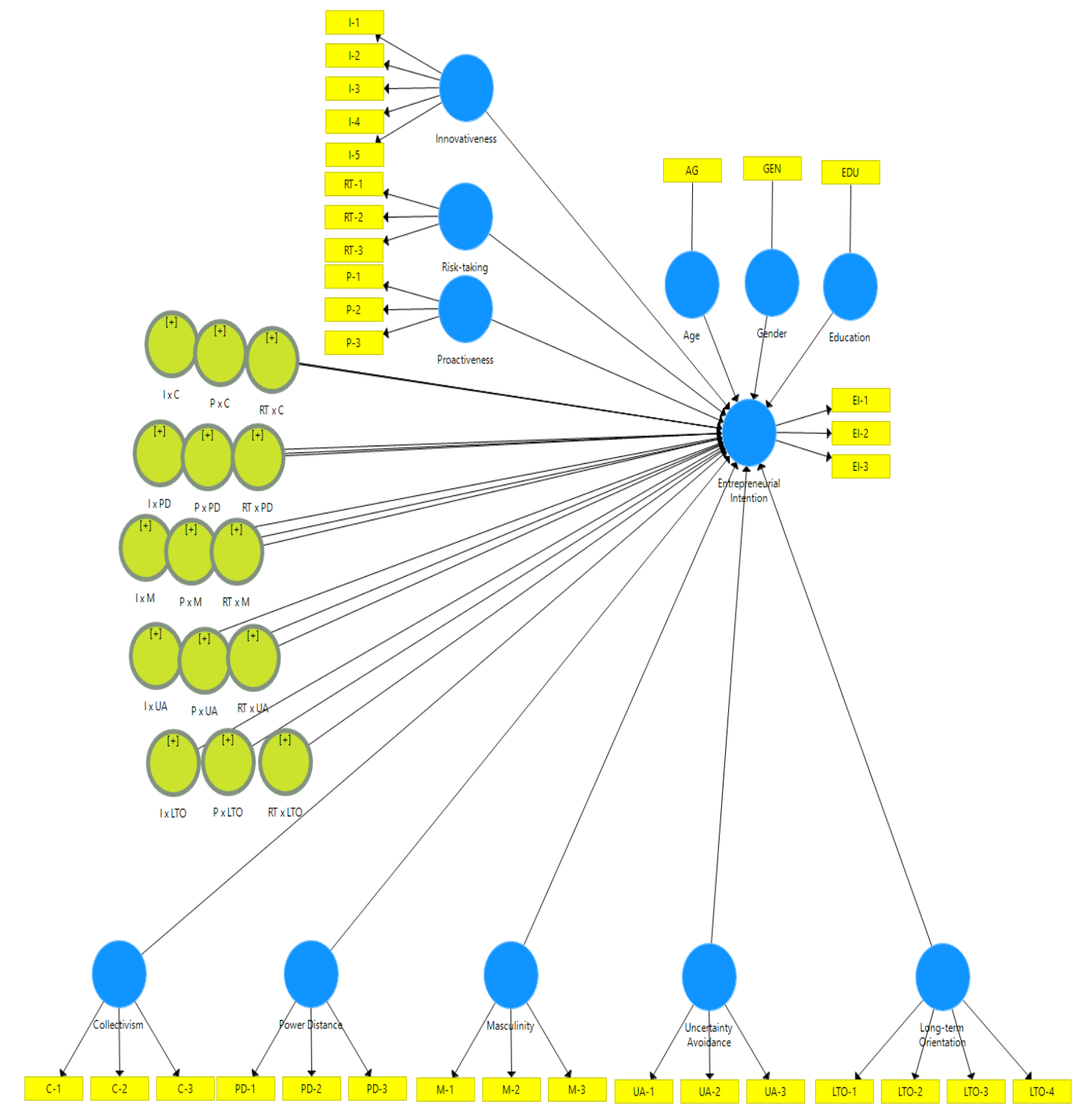

Figure 1. A Moderation Model Using Cultural Dimensions

Above model demonstrates the impacts of those three independent factors alongside the moderating factors on to the dependent variable (Entrepreneurial Intention).

\section{Risk Taking Affect EI}

Risk taking is firmly connected with entrepreneurship (Genever, 2017). All organizations include risk taking, yet that risks ought to be ascertains not arbitrary bets. Risks are including in enlisting representatives, advertising methodologies and furthermore for the client administrations. Taking risks enables a person to step toward their objectives. (Tipu, 2017) contributes on entrepreneurial risk taking, by investigating significant subjects in entrepreneurial risk taking.

\section{Pro-activeness Affect EI}

Pro-activeness is an unavoidable wonder in entrepreneurial associations (Zhao \& Smallbone, 2017). For the most part individuals do look into on entrepreneurial expectation at the degree 
of firms, not the person. (Zhao \& Smallbone, 2017) infer that pro-activeness has a huge and positive association with entrepreneurship, though methodical inquiry and the executive's instruction have a negative impact. (Prabhu, McGuire, Drost, \& Kwong, 2012) discovered that proactive personality has a strong association with entrepreneurial aim. Pro-activeness is likewise the powerful indicator of later conduct in entrepreneurship.

\section{Innovativeness Affect EI}

(Bayram, Nihat, \& Can, 2016) demonstrated that there is a long haul connection without a sign for the momentary connection among entrepreneurship and development. Entrepreneurs who embrace the component of innovativeness should quicken innovative exercises they get upper hand.

\section{Cultural Dimensions Affect EI}

(Hofstede, Dimensionalizing Cultures: The Hofstede Model in Context, 2001) investigates the distinctions in deduction and social activity that exists among individuals from in excess of 50 current countries. By examining the parts of national culture that a portion of the projects contain, recommend an idea that individuals convey mental projects that officially created in the family in early youth and fortified on schools and associations. Various components of culture that influences entrepreneurial goals and likewise talked about by (Hofstede, Dimensionalizing Cultures: The Hofstede Model in Context, 2001) are uncertainty avoidance, individualism versus collectivism, long term versus short term orientation, power distance and masculinity versus femininity. (Weerawardena \& Mort, 2006) utilizing grounded hypothesis strategy and with the assistance of various nine top to bottom contextual analyses contributes towards entrepreneurship. Moreover, they found that social entrepreneurial associations need to embrace culture went for innovativeness, risk taking and pro-activeness.

\subsection{Research Hypotheses}

$\mathbf{H}_{1}$ : Innovativeness has a significant impact on Entrepreneurial Intention.

$\mathbf{H}_{2}$ : Power Distance moderate the significant impact of Innovativeness on Entrepreneurial Intention.

$\mathbf{H}_{3}$ : Collectivism moderate the significant impact of Innovativeness on Entrepreneurial Intention.

$\mathbf{H}_{4}$ : Uncertainty Avoidance moderate the significant impact of Innovativeness on Entrepreneurial Intention.

H5: Masculinity moderate the significant impact of Innovativeness on Entrepreneurial Intention.

$\mathbf{H}_{6}$ : Long Term Orientation moderate the significant impact of Innovativeness on Entrepreneurial Intention.

H7: Risk Taking has a significant impact on Entrepreneurial Intention.

$\mathbf{H}_{8}$ : Power Distance moderate the significant impact of Risk Taking on Entrepreneurial 
Intention.

$\mathbf{H}_{9}$ : Collectivism moderate the significant impact of Risk Taking on Entrepreneurial Intention.

$\mathbf{H}_{10}$ : Uncertainty Avoidance moderate the significant impact of Risk Taking on Entrepreneurial Intention.

$\mathbf{H}_{11}$ : Masculinity moderate the significant impact of Risk Taking on Entrepreneurial Intention.

$\mathbf{H}_{12}$ : Long Term Orientation moderate the significant impact of Risk Taking on Entrepreneurial Intention.

$\mathbf{H}_{13}$ : Pro-Activeness has a significant impact on Entrepreneurial Intention.

$\mathbf{H}_{14}$ : Power Distance moderate the significant impact of Pro-Activeness on Entrepreneurial Intention.

$\mathbf{H}_{15}$ : Collectivism moderate the significant impact of Pro-Activeness on Entrepreneurial Intention.

H16: Uncertainty Avoidance moderate the significant impact of Pro-Activeness on Entrepreneurial Intention.

$\mathbf{H}_{17}$ : Masculinity moderate the significant impact of Pro-Activeness on Entrepreneurial Intention.

H18: Long Term Orientation moderate the significant impact of Pro-Activeness on Entrepreneurial Intention.

$\mathbf{H}_{19}$ : Power Distance has a significant impact on Entrepreneurial Intention.

$\mathbf{H}_{\mathbf{2 0}}$ : Collectivism has a significant impact on Entrepreneurial Intention.

$\mathbf{H}_{21}$ : Uncertainty Avoidance has a significant impact on Entrepreneurial Intention.

$\mathbf{H}_{22}$ : Masculinity has a significant impact on Entrepreneurial Intention.

$\mathbf{H}_{23}$ : Long Term Orientation has a significant impact on Entrepreneurial Intention.

$\mathbf{H}_{24}$ : Gender has a significant impact on Entrepreneurial Intention.

$\mathbf{H}_{25}$ : Age has a significant impact on Entrepreneurial Intention.

$\mathbf{H}_{26}$ : Education has a significant impact on Entrepreneurial Intention.

\section{Research Methodology}

\subsection{Sampling Technique}

The respondents were selected using stratified and convenience sampling to increase the statistical efficiency of samples and to provide assurance that the sample will accurately reflect the population. Data were accumulated among March and April 2019, emails were 


\section{I Macrothink}

International Journal of Human Resource Studies

ISSN 2162-3058 2020, Vol. 10, No. 1

sent to the respondents and data were collected manually as well. This technique ensured consistency across Pakistan to the extent instrument position, data get-together and diagram timing.

\subsection{Sampling Size}

The review is led among 272 respondents. Population consist of both male and female - lower, middle and top level management. Accordingly, our chosen sample is rather heterogeneous; permitting us to take a look at manageable effects of other external variables like uncertainty avoidance, masculinity, collectivism, power distance, long term orientation, age, gender and education.

\subsection{Questionnaire Design}

Questionnaire have been adopted from (Richter, et al., 2016), consists of different constructs i.e. gender, age, education (P-Y, E, V, \& CR, 2018) and other constructs like power distance, uncertainty avoidance, collectivism, long term orientation, masculinity, innovativeness, risk taking, pro-activeness, entrepreneurial intention (Richter, et al., 2016). Five response replacements were utilized rendering to Likert-Scale ( $1=$ Strongly Disagree, $2=$ Little Extent or Disagree, $3=$ Moderate Extent or Not Sure, $4=$ Great Extent or Agree, and $5=$ Strongly Agree) (Macko \& Tyszka, 2009). Mostly data has been accrued manually through personal contacts and some of the statistics has been accumulated through google form.

\section{Demographic Analysis}

Table 1. Descriptive Statistics (Demographic Summary)

\begin{tabular}{|l|l|l|}
\hline Demographic Profile & Category & Percentage \\
\hline Gender & Male & $40.1 \%$ \\
\hline & Female & $59.9 \%$ \\
\hline Age & $21-25$ & $44.5 \%$ \\
\hline & $26-30$ & $29.2 \%$ \\
\hline & $31-35$ & $10.9 \%$ \\
\hline & $36-40$ & $7.4 \%$ \\
\hline Education & Above 40 & $8 \%$ \\
\hline & Under-graduation & $13.9 \%$ \\
\hline & Graduation & $17.5 \%$ \\
\hline & Post-graduation & $41.6 \%$ \\
\hline & MS/M.Phil. & $21.9 \%$ \\
\hline & PhD & $5.1 \%$ \\
\hline
\end{tabular}

Descriptive statistics in the arrangement of frequencies and percentage are consequently graphically accessible for each of the above-stated variables. It can be perceived from the table that the most of the respondents, that is $59.9 \%(n=272)$ were females and the remaining $40.1 \%(n=272)$ was cooperated of males.

From the frequency distribution obtainable, it may be presumed that a total of $44.5 \%$ 
respondents in the sample are between the ages of 21 and 25. It can thus be perceived that the majority of the people in the sample drop into this classification. This is followed by 26 to 30 years' age category into which $29.2 \%(\mathrm{n}=272)$ of the respondents fall. Only $10.9 \%$ of the respondents are lies between 31 to 35 and $7.4 \%$ of the respondents falls in an interval between 36 to 40 . While only $8 \%$ of the respondents specified that they are elder than 40 years.

It is observed that $13.9 \%$ of the respondents are reported to be under-graduate. As regards to $17.5 \%$ of the respondents have expressed that they studied up to graduation, followed by $41.6 \%, 21.6 \%$ and $5.1 \%$ of the respondents have informed that they were educated up to post-graduation, MS/M.Phil. and PhD.

\section{Descriptive Statistics}

Table 2. Descriptive Statistics (Items Original Sample, Sample Mean \& Std. Deviation)

\begin{tabular}{|c|c|c|c|}
\hline Survey Question & $\begin{array}{l}\text { Original } \\
\text { Sample } \\
\text { (O) }\end{array}$ & $\begin{array}{l}\text { Sample } \\
\text { Mean } \\
\text { (M) }\end{array}$ & $\begin{array}{l}\text { Standard } \\
\text { Deviation } \\
\text { (STDEV) }\end{array}$ \\
\hline AG $<$ - Age & 1.000 & 1.000 & 0.000 \\
\hline C-1 <- Group loyalty should be encouraged even if individual goals suffer. & 0.881 & 0.882 & 0.028 \\
\hline C-2 <- Group welfare is more important than individual rewards. & 0.839 & 0.837 & 0.035 \\
\hline C-3 <- Group success is more important than individual success. & 0.825 & 0.822 & 0.044 \\
\hline EDU $<$ - Education & 1.000 & 1.000 & 0.000 \\
\hline EI-1 <- To what extent have you considered starting your own business? & 0.889 & 0.889 & 0.016 \\
\hline EI-2 <- To what extent have you prepared to start your own business? & 0.851 & 0.852 & 0.024 \\
\hline $\begin{array}{l}\text { EI-3 <- How likely is it that you are going to start your own business within the next } 5 \\
\text { years? }\end{array}$ & 0.896 & 0.896 & 0.014 \\
\hline GEN <- Gender & 1.000 & 1.000 & 0.000 \\
\hline I-1 <-I often surprise people with my novel ideas. & 0.769 & 0.769 & 0.031 \\
\hline I-2 <- People often ask me for help in creative activities. & 0.887 & 0.888 & 0.015 \\
\hline I-3 <-I prefer work that requires original thinking. & 0.860 & 0.859 & 0.020 \\
\hline I-4<-I like a job that demands skill and practice rather than inventiveness. & 0.729 & 0.726 & 0.047 \\
\hline I-5 $<-$ I am not a very creative person. & 0.203 & 0.196 & 0.091 \\
\hline LTO-1 <- Careful management of money (thrift). & 0.828 & 0.828 & 0.024 \\
\hline LTO-2 <- Personal steadiness and stability. & 0.751 & 0.747 & 0.045 \\
\hline LTO-3 <- Long-term planning. & 0.909 & 0.909 & 0.016 \\
\hline LTO-4 <- Working hard for success in the future. & 0.902 & 0.903 & 0.010 \\
\hline M-1 <- There are some jobs that a man can always do better than a woman. & 0.874 & 0.877 & 0.047 \\
\hline $\begin{array}{l}\text { M-2 <- Solving difficult problems usually requires an active, forcible approach, which is } \\
\text { typical of men. }\end{array}$ & 0.712 & 0.691 & 0.099 \\
\hline M-3 <-It is more important for men to have a professional career than it is for women. & 0.737 & 0.718 & 0.092 \\
\hline P-1 <- Seeing the 'big picture' comes easy for me. & 0.804 & 0.801 & 0.036 \\
\hline P-2 <- One of my skills is being good at making things work. & 0.874 & 0.875 & 0.023 \\
\hline P-3 <-I enjoy working out strategies for my organization's growth. & 0.855 & 0.856 & 0.022 \\
\hline $\begin{array}{l}\text { PD-1 <- People in higher positions should avoid social interaction with people in lower } \\
\text { positions. }\end{array}$ & 0.809 & 0.636 & 0.302 \\
\hline $\begin{array}{l}\text { PD-2 <- People in higher positions should not ask the opinions of people in lower } \\
\text { positions too frequently. }\end{array}$ & 0.461 & 0.585 & 0.384 \\
\hline $\begin{array}{l}\text { PD-3<- People in higher positions should make most decisions without consulting people } \\
\text { in lower positions. }\end{array}$ & 0.892 & 0.696 & 0.317 \\
\hline RT-1 <-I am always willing to take a moderate risk to get ahead. & 0.860 & 0.860 & 0.019 \\
\hline RT-2<-I like the feeling that comes from entering a new situation. & 0.850 & 0.849 & 0.028 \\
\hline RT-3 <- The greater the risk the more fun the activity. & 0.850 & 0.848 & 0.031 \\
\hline UA-1 <-Instructions for operations are important. & 0.900 & 0.899 & 0.012 \\
\hline $\begin{array}{l}\text { UA-2 <- It is important to have instructions spelled out in detail so that I always know } \\
\text { what I'm expected to do. }\end{array}$ & 0.874 & 0.873 & 0.024 \\
\hline $\begin{array}{l}\text { UA-3<- Rules and regulations are important because they inform me of what is expected } \\
\text { of me. }\end{array}$ & 0.856 & 0.855 & 0.026 \\
\hline
\end{tabular}

The construct power distance incorporates three inquiries. These inquiry comprises of connection between individuals at higher level and individuals at lower level, that upper level people ought to maintain a strategic distance from social association, abstain from asking 
opinions and settle on most choices without counselling individuals in lower positions. In the wake of gathering the information, in excess of 50 percent individuals demonstrated least agreement with this sort of assessment. Generally, respondents are supportive of good connection among upper and lower level positions.

Other build uncertainty avoidance additionally comprises of three questions. This build accepts that we should control different people appropriately to maintain a strategic distance from any irregular conditions and consistently keep association or individual on a protected side. Offering directions to workers in detail for fruitful tasks is important, so representative realize that what he is relied upon to do. Likewise give him the rules about guidelines and guidelines to dodge any uncertainty. In answering to these inquiries, in excess of 40 percent respondents demonstrated highest level of agreement, that legitimate guidelines to worker is significant. Individuals put stock in to manage appropriately to their sub-ordinates to show signs of improvement results.

Collectivism is another dimension of culture. We have posed three inquiries in regards to cooperation. Individuals ought to be faithful to their gathering and that propensity ought to be supported, bunch welfare and gathering success could easily compare to people rewards or success. Over half respondents demonstrated moderate extent and not secure with these inquiries, yet over $25 \%$ concurred that gathering success or rewards could really compare to people success or rewards.

Another dimension of a culture, long term orientation includes four questions. These inquiries were about long term planning, personal steadiness and stability, careful management of money and working hard for success in the future. About careful management of money, personal steadiness and stability respondents indicated moderate extent. Though, about long term planning and working hard for success in the future, over half respondents demonstrated highest agreement. That mean individuals puts stock in long term technique however not secure with how to do planning viably and effectively.

Masculinity is also included in our examination, consists of three inquiries. There is an idea that a few jobs that man can always do better than a woman, about this inquiry respondents reactions were blend, over $30 \%$ accepts that this idea is not valid, however over $25 \%$ respondents were agreed to above statement. Other inquiry concerning masculinity resembled solving difficult problems usually requires and active, forcible approach, which is typical of men, regarding to this inquiry regarding $40 \%$ individuals demonstrated moderate extent and over $35 \%$ individuals were least agreed. In addition, also asked that it is important for men to have a professional career than it is for women, because of this inquiry concerning half of the respondents demonstrated least agreement. Thus, we can analyze that individuals have confidence in equality in Pakistan.

Another factor innovativeness is an important dimension of entrepreneurship, consisting of five inquiries. More than $35 \%$ respondents often surprise people with their novel ideas, and more than $50 \%$ respondents said that people often ask them for help in creative activities and they prefer work that requires original thinking. More than 35\% thought that they like a job that demands skill and practice rather than inventiveness. However, for the most part, like 
about $50 \%$ of respondents thought that they are not a very creative person. Individuals do not have faith on themselves.

Another main dimension of entrepreneurship is risk taking, includes three inquiries. For the most part people do not take risks in Pakistan, higher ratio of respondents indicated moderate extent. About $25 \%$ respondents willing to take a moderate risk, likes the feeling that comes from entering a new situation and believes in greater the risk the more fun the activity. In this way, we can analyze that for the most part people are afraid off taking risks because of failure and the individuals who take risk are less in numbers.

Pro-activeness is another dimension of entrepreneurship; this construct was consisting on three questions. Mostly people are not able to seeing the 'big picture' and showed moderate extent regarding this questions. Be that as it may, about $40 \%$ of respondents believes they enjoy working out strategies for their organization's growth and there are good in making things work. We can finish up according to our responses that people are willing to give their suggestions and attempt to be pro-active.

Finally, the main construct, entrepreneurship includes three distinct questions. About $40 \%$ respondents considered to start their own business, however more than $40 \%$ people were not sure about it. Out of $40 \%$ respondents more than $20 \%$ people who have considered to start their business are currently prepared to start their own business. Moreover, more than 35\% people are going to start their business within next 5 years. We can reason that people want to do their business, yet because of various circumstances including environment they fail to start their very own business.

\subsection{Structural Equation Modelling}

Structural Equation Model (SEM) has been utilized to test the hypothesis through SmartPLS. It identifies the relationship between endogenous and exogenous variables. The foremost technique utilized underneath different regression models and methods in structural equation model (Baron \& David A. Kenny, 1986). Bootstrapping alongside structural equation model has been seen as most appropriate for huge and little example size, therefore utilizing this model has been applied (Hayes, 2013). A technique of bootstrapping to check all indirect and direct effects has been implemented (Shrout \& Bolger, 2002).

\subsection{Measurement of Outer Model}

Through this external model, we build up a structure that considers a superior comprehension of the connections (Niehaves \& Ortbach, 2016). So as to check the validity and reliability Smart PLS has been utilized. This model best portrays the connection among latent variables and indicators. Outer model is the device to satisfy and fortify the variables for any exploration (Friedman \& Honzik, 2016). 


\section{Macrothink}

International Journal of Human Resource Studies

\section{Composite Reliability}

By utilizing composite reliability, the reliability of the measurement instruments was evaluated. Every one of the values were over the ordinarily utilized threshold esteem for example 0.70 . This is the accepted reliability worth range. Estimation of reliability should be possible by level of constancy that lies amongst different variables (Joseph F. Hair, Black, Babin, \& Anderson, 2010). Below is the table of composite reliability.

Table 3. Composite Reliability

\begin{tabular}{|l|l|}
\hline Variables & Composite Reliability \\
\hline Age & 1.000 \\
\hline Collectivism & 0.885 \\
\hline Education & 1.000 \\
\hline Entrepreneurial Intention & 0.911 \\
\hline Gender & 1.000 \\
\hline I X C & 1.000 \\
\hline I x LTO & 1.000 \\
\hline I X M & 1.000 \\
\hline I x PD & 1.000 \\
\hline I U UA & 1.000 \\
\hline Innovativeness & 0.837 \\
\hline Long-term Orientation & 0.912 \\
\hline Masculinity & 0.820 \\
\hline Px C & 1.000 \\
\hline Px LTO & 1.000 \\
\hline Px M & 1.000 \\
\hline Px PD & 1.000 \\
\hline Px UA & 1.000 \\
\hline Power Distance & 0.778 \\
\hline Pro-activeness & 0.882 \\
\hline RT x C & 1.000 \\
\hline RT x LTO & 1.000 \\
\hline RT x M & 1.000 \\
\hline RT x PD & 1.000 \\
\hline RT x UA & 1.000 \\
\hline Risk-taking & 0.889 \\
\hline Uncertainty Avoidance & 0.909 \\
\hline
\end{tabular}

\section{Factor loadings significant}

Below is the mentioned table of (CFA) confirmatory factor analysis with the loadings. To analyse the fit of that specific model we force the factors to load just on specific variables. Above 0.5 are strong and underneath 0.5 are weak loading factors (Prudon, 2015). 
Table 4. Outer Loadings

\begin{tabular}{|c|c|c|c|c|}
\hline Survey Question & Constructs & $\begin{array}{l}\text { Item } \\
\text { Loading }\end{array}$ & $\begin{array}{l}\text { T } r \text { Statistics } \\
(|\mathrm{O} / \mathrm{STDEV}|)\end{array}$ & $\begin{array}{l}\mathbf{P} \\
\text { Values }\end{array}$ \\
\hline AG $<$ - Age & Age & 1 & & \\
\hline $\begin{array}{l}\text { C-1 }<\text { Group loyalty should be encouraged even if } \\
\text { individual goals suffer. }\end{array}$ & \multirow[t]{3}{*}{ Collectivism } & 0.881 & 31.50 & 0.00 \\
\hline $\begin{array}{l}\mathrm{C}-2<\text { Group welfare is more important than individual } \\
\text { rewards. }\end{array}$ & & 0.839 & 24.17 & 0.00 \\
\hline $\begin{array}{l}\text { C- } 3<\text { - Group success is more important than individual } \\
\text { success. }\end{array}$ & & 0.825 & 18.92 & 0.00 \\
\hline EDU $<$ - Education & Education & 1 & & \\
\hline $\begin{array}{l}\text { EI- } 1<\text { To what extent have you considered starting your } \\
\text { own business? }\end{array}$ & \multirow[t]{3}{*}{$\begin{array}{l}\text { Entrepreneurial } \\
\text { Intention }\end{array}$} & 0.889 & 55.40 & 0.00 \\
\hline $\begin{array}{l}\text { EI- } 2<- \text { To what extent have you prepared to start your } \\
\text { own business? }\end{array}$ & & 0.851 & 35.27 & 0.00 \\
\hline $\begin{array}{l}\text { EI- } 3<\text { How likely is it that you are going to start your } \\
\text { own business within the next } 5 \text { years? }\end{array}$ & & 0.896 & 62.01 & 0.00 \\
\hline GEN $<$ - Gender & Gender & 1 & & \\
\hline I-1 <- I often surprise people with my novel ideas. & \multirow[t]{5}{*}{ Innovativeness } & 0.769 & 24.74 & 0.00 \\
\hline I- $2<$ People often ask me for help in creative activities. & & 0.887 & 60.86 & 0.00 \\
\hline I-3 $<$ - I prefer work that requires original thinking. & & 0.86 & 42.60 & 0.00 \\
\hline $\begin{array}{l}\text { I- } 4<\text { I like a job that demands skill and practice rather } \\
\text { than inventiveness. }\end{array}$ & & 0.729 & 15.39 & 0.00 \\
\hline $\mathrm{I}-5<$ I am not a very creative person. & & 0.203 & 2.22 & 0.03 \\
\hline LTO-1 <-Careful management of money (thrift). & \multirow{4}{*}{$\begin{array}{l}\text { Long Tem } \\
\text { Orientation }\end{array}$} & 0.828 & 34.24 & 0.00 \\
\hline LTO-2 $<$ - Personal steadiness and stability. & & 0.751 & 16.73 & 0.00 \\
\hline LTO-3 $<$ - Long-term planning. & & 0.909 & 57.02 & 0.00 \\
\hline LTO-4 $<$ - Working hard for success in the future. & & 0.902 & 86.92 & 0.00 \\
\hline $\begin{array}{l}\text { M- } 1<\text { There are some jobs that a man can always do } \\
\text { better than a woman. }\end{array}$ & \multirow[t]{3}{*}{ Masculinity } & 0.874 & 18.55 & 0.00 \\
\hline $\begin{array}{l}\text { M-2 < Solving difficult problems usually requires an } \\
\text { active, forcible approach, which is typical of men. }\end{array}$ & & 0.712 & 7.16 & 0.00 \\
\hline $\begin{array}{l}\text { M-3 }<\text { - It is more important for men to have a professional } \\
\text { career than it is for women. }\end{array}$ & & 0.737 & 8.02 & 0.00 \\
\hline P-1 <- Seeing the "big picture" comes easy for me. & \multirow[t]{3}{*}{ Pro-activeness } & 0.804 & 22.28 & 0.00 \\
\hline $\begin{array}{l}\text { P- } 2<\text { One of my skills is being good at making things } \\
\text { work. }\end{array}$ & & 0.874 & 38.15 & 0.00 \\
\hline $\begin{array}{l}\text { P-3 < I enjoy working out strategies for my } \\
\text { organization's growth. }\end{array}$ & & 0.855 & 39.00 & 0.00 \\
\hline $\begin{array}{l}\text { PD-1 < People in higher positions should avoid social } \\
\text { interaction with peoplein lowerpositions. }\end{array}$ & \multirow[t]{3}{*}{$\begin{array}{l}\text { Power } \\
\text { Distance }\end{array}$} & 0.809 & 2.68 & 0.01 \\
\hline $\begin{array}{l}\text { PD- } 2<\text { People in higher positions should not ask the } \\
\text { opinions of people in lower positions too frequently. }\end{array}$ & & 0.461 & 1.20 & 0.23 \\
\hline $\begin{array}{l}\text { PD- } 3<\text { People in higher positions should make most } \\
\text { decisions without consulting people in lower positions. }\end{array}$ & & 0.892 & 2.81 & 0.01 \\
\hline $\begin{array}{l}\text { RT-1 }<\text { I am always willing to take a moderate risk to get } \\
\text { ahead. }\end{array}$ & \multirow[t]{3}{*}{ Risk Taking } & 0.86 & 45.74 & 0.00 \\
\hline $\begin{array}{l}\text { RT- } 2<- \text { I like the feeling that comes from entering a new } \\
\text { situation. }\end{array}$ & & 0.85 & 30.57 & 0.00 \\
\hline RT $-3<-$ The greater the risk the more fun the activity. & & 0.85 & 27.32 & 0.00 \\
\hline UA-1 $<$ - Instructions for operations are important. & \multirow{3}{*}{$\begin{array}{l}\text { Uncertainty } \\
\text { Avoidance }\end{array}$} & 0.9 & 75.46 & 0.00 \\
\hline $\begin{array}{l}\text { UA-2 < It is important to have instructions spelled out in } \\
\text { detail so that I always know what I'm expected to do. }\end{array}$ & & 0.874 & 36.11 & 0.00 \\
\hline $\begin{array}{l}\text { UA-3 }<\text { Rules and regulations are important because they } \\
\text { inform me of what is expected of me. }\end{array}$ & & 0.856 & 32.56 & 0.00 \\
\hline
\end{tabular}

\section{Convergent Validity}

Reliability test has been used to measure internal consistency. Reliability and validity of variables Cronbach alpha is used as a tool in Smart PLS in order to examine. Cronbach alpha is the most common tool that plaid the survey questions' validity and reliability. 


\section{MInstitute ${ }_{\text {Mnk }}^{\text {Macrothink }}$}

International Journal of Human Resource Studies

ISSN 2162-3058

Convergent validity is the level of agreement in at least two measures of a similar construct (Carmines \& Zeller, 1979). Convergent validity was assessed by inspection of variance mined for each factor (Fornell \& F. Larker, 1981). Affirmation was tried for the reliability by Cronbach's Alpha (Cronbach \& Shavelson, 2004), as indicated by (Chin, 1998) the variable estimation of more than 0.6 is estimated dependable yet estimation of more than 0.7 is favoured. Further, to test the validity and dependability of the items utilized, confirmatory factor analysis and exploratory investigation was carries out.

Following table displays the result.

Table 5. Reliability Test

\begin{tabular}{|c|c|c|c|c|}
\hline Variables & Cronbach's Alpha & rho_A & $\begin{array}{l}\text { Composite } \\
\text { Reliability }\end{array}$ & $\begin{array}{l}\text { Average } \\
\text { Variance } \\
\text { Extracted } \\
\text { (AVE) }\end{array}$ \\
\hline Age & 1.000 & 1.000 & 1.000 & 1.000 \\
\hline Collectivism & 0.810 & 0.845 & 0.885 & 0.721 \\
\hline Education & 1.000 & 1.000 & 1.000 & 1.000 \\
\hline Entrepreneurial Intention & 0.853 & 0.860 & 0.911 & 0.772 \\
\hline Gender & 1.000 & 1.000 & 1.000 & 1.000 \\
\hline I x C & 1.000 & 1.000 & 1.000 & 1.000 \\
\hline I x LTO & 1.000 & 1.000 & 1.000 & 1.000 \\
\hline I x M & 1.000 & 1.000 & 1.000 & 1.000 \\
\hline I x PD & 1.000 & 1.000 & 1.000 & 1.000 \\
\hline I x UA & 1.000 & 1.000 & 1.000 & 1.000 \\
\hline Innovativeness & 0.747 & 0.840 & 0.837 & 0.538 \\
\hline Long-term Orientation & 0.872 & 0.895 & 0.912 & 0.722 \\
\hline Masculinity & 0.696 & 0.803 & 0.820 & 0.605 \\
\hline $\mathbf{P} \times \mathbf{C}$ & 1.000 & 1.000 & 1.000 & 1.000 \\
\hline Px LTO & 1.000 & 1.000 & 1.000 & 1.000 \\
\hline PxM & 1.000 & 1.000 & 1.000 & 1.000 \\
\hline Px PD & 1.000 & 1.000 & 1.000 & 1.000 \\
\hline Px UA & 1.000 & 1.000 & 1.000 & 1.000 \\
\hline Power Distance & 0.787 & -0.065 & 0.778 & 0.555 \\
\hline Pro-activeness & 0.799 & 0.799 & 0.882 & 0.714 \\
\hline RT x C & 1.000 & 1.000 & 1.000 & 1.000 \\
\hline RT $\times$ LTO & 1.000 & 1.000 & 1.000 & 1.000 \\
\hline RT x M & 1.000 & 1.000 & 1.000 & 1.000 \\
\hline RT x PD & 1.000 & 1.000 & 1.000 & 1.000 \\
\hline RT x UA & 1.000 & 1.000 & 1.000 & 1.000 \\
\hline Risk-taking & 0.813 & 0.815 & 0.889 & 0.728 \\
\hline Uncertainty Avoidance & 0.850 & 0.850 & 0.909 & 0.769 \\
\hline
\end{tabular}

Entrepreneurial Intention is the dependent variable in the research having a reliability value of 0.853 that shows that the data is reliable and highly valid. Independent variables i.e. age, gender, education, innovativeness, risk-taking, pro-activeness, power distance, uncertainty avoidance, long term orientation and collectivism shows the reliability of more than 0.7 which is highly acceptable in contrast with entrepreneurial intention. Masculinity is considered as independent variable in the research and the assessment of Cronbach alpha is to be 0.696 which is not very good but can be considered significant as it is more than 0.4 and it can be considered as 0.7 when we round off the figure. 


\section{Ml Macrothink}

International Journal of Human Resource Studies

ISSN 2162-3058

2020, Vol. 10, No. 1

Moderating variables i.e. all cultural dimensions (uncertainty avoidance, masculinity, power distance, collectivism and long term orientation) along with pro-activeness, innovativeness and risk-taking also shows the reliability of more than 0.7 with that of the entrepreneurial intention and the validity is considered to be excellent.

\subsection{Discriminant Validity}

At the point when diagonal elements are significantly higher than off-diagonal in parallel columns and rows then discriminant validity is established. It alludes to any single construct in the model when contrast from other constructs (Carmines \& Zeller, 1979). At the point when the AVE loading is more than 0.5 of the constructs, it implies the discriminant validity results are satisfactory (Chin, 1998).

Table 6. Heterotrait-Monotrait Ratio (HTMT)

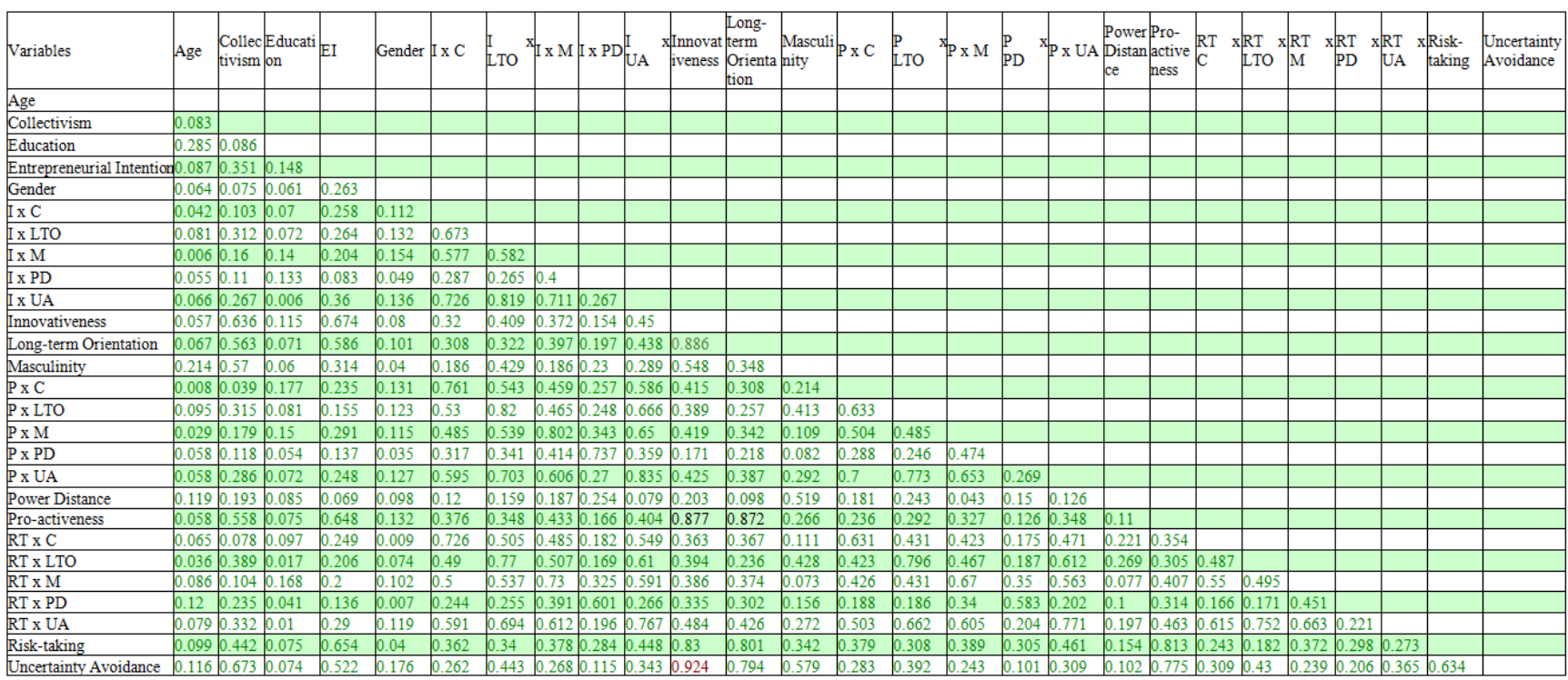

\subsection{Model Fit Measures}

The relationship between each build is assessed through the saturated model. This model relies upon the absolute impact conspire by considering as a model structure. Whereas this model is characterized by d ULS, normal fit index (NFI), exact model fits like and $\mathrm{d} G, \chi^{2}$ (Chi-square) and standardized root mean square residual (SRMR) as well.

Table 7. Model Fit

\begin{tabular}{|l|l|l|}
\hline Fit Summary & Saturated Model & Estimated Model \\
\hline SRMR & 0.074 & 0.074 \\
\hline d_ULS & 3.109 & 3.095 \\
\hline d_G & 1.554 & 1.550 \\
\hline Chi-Square & $2,339.103$ & $2,318.514$ \\
\hline NFI & 0.622 & 0.626 \\
\hline
\end{tabular}

\subsection{Hypothesis Testing}

In PLS-SEM, bootstrapping is one of the key stride, which gives the data of constancy of factor guesstimate. Sub-tests are drawn everywhere from the first example including 


\section{Macrothink}

substitution, in this process (Hair, Matthews, Matthews, \& Sarstedt, 2017). In the wake of running the bootstrap schedule, the t-values for the model can be squared in Smart PLS. If t-values greater than $1.96(\mathrm{p}<.005)$, then the relationship at $95 \%$ confidence level is significant. The $\mathrm{p}$-value which is less than 0.05 would indicate a significant difference between two means. Paths through SmartPLS shows the relationship between latent and measured variable. The path diagram exhibited in figure 2.

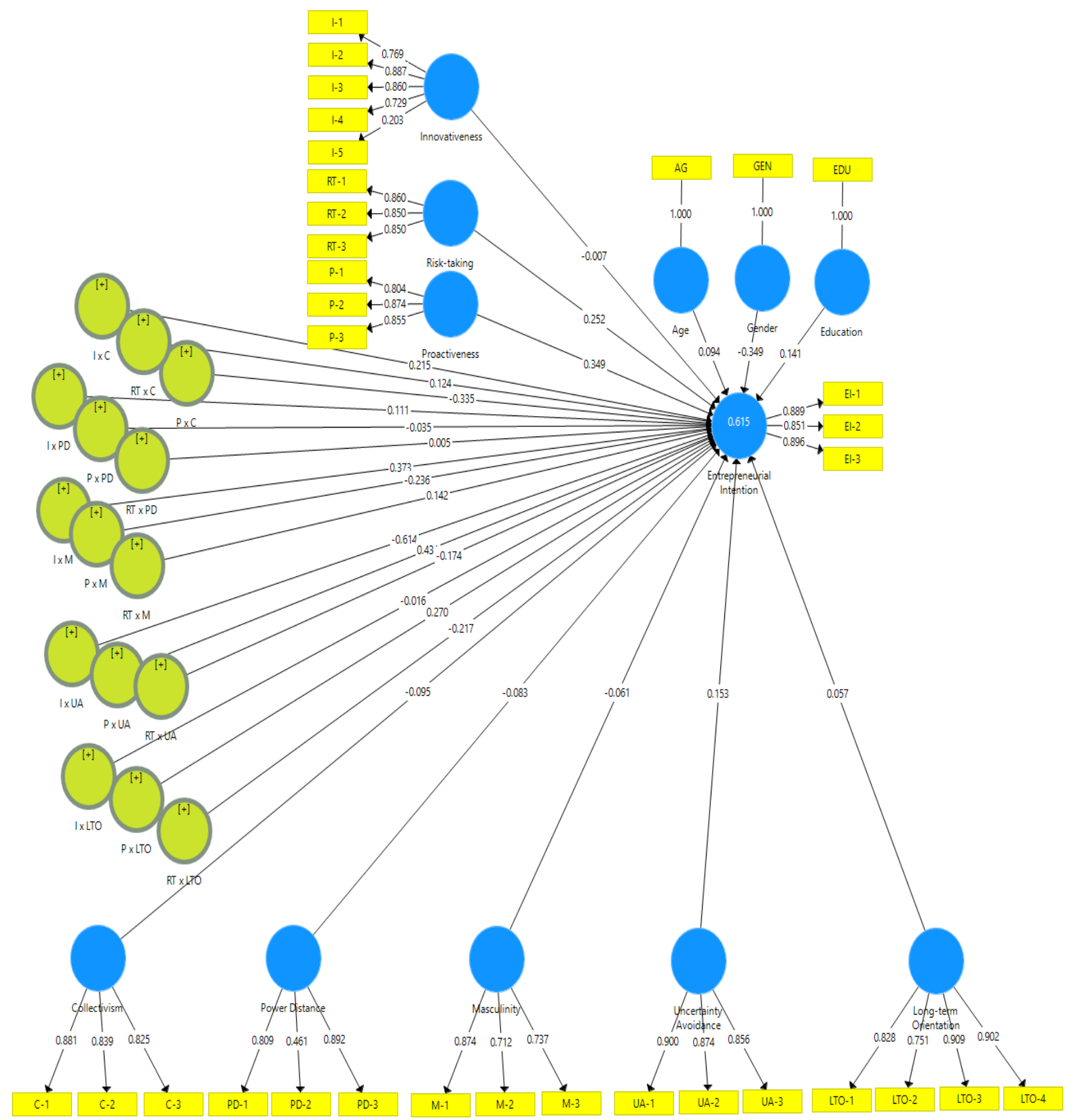

Figure 2. Path Diagram

Linear regression in Smart PLS is used to predict or forecast that the value of one variable is linked or based on the value of another variable. It will guide us the link between model and the dependent variable on a suitable 0-100 percent scale. 
Table 8. Model Summary

\begin{tabular}{|l|l|l|}
\hline & R Square & R Square Adjusted \\
\hline Entrepreneurial Intention & 0.615 & 0.574 \\
\hline
\end{tabular}

Table 8. displays that value of $\mathrm{R}$ square is 0.615 that shows that the relation between dependent and independent variable is the best fit and there is movement in the index that is why it is near to 100 percent. 61 percent of the statics indicates that change in dependent variable is explicated by the independent variable.

Table 9. Hypotheses

\begin{tabular}{|l|l|l|l|l|}
\hline Hypothesis & Coefficients & T -values & P-values & Decision \\
\hline $\begin{array}{l}\mathrm{H}_{1}: \text { Innovativeness has a significant } \\
\text { impact on Entrepreneurial Intention. }\end{array}$ & -0.01 & 0.07 & 0.94 & Unsupported \\
\hline $\begin{array}{l}\mathrm{H}_{2}: \text { Power Distance moderate the } \\
\text { significant impact of Innovativeness } \\
\text { on Entrepreneurial Intention. }\end{array}$ & 0.11 & 1.09 & 0.27 & Unsupported \\
\hline $\begin{array}{l}\mathrm{H}_{3}: \text { Collectivism moderate the } \\
\text { significant impact of Innovativeness } \\
\text { on Entrepreneurial Intention. }\end{array}$ & 0.22 & 1.69 & 0.09 & Unsupported \\
\hline $\begin{array}{l}\mathrm{H}_{4}: \text { Uncertainty Avoidance moderate } \\
\text { the significant impact of } \\
\text { Innovativeness on Entrepreneurial } \\
\text { Intention. }\end{array}$ & -0.61 & 4.78 & 0.00 & Supported \\
\hline $\begin{array}{l}\mathrm{H}_{5}: \text { Masculinity moderate the } \\
\text { significant impact of Innovativeness } \\
\text { on Entrepreneurial Intention. }\end{array}$ & 0.37 & 3.20 & 0.00 & Supported \\
\hline $\begin{array}{l}\mathrm{H}_{6}: \text { Long Term Orientation moderate } \\
\text { the significant impact of } \\
\text { Innovativeness on Entrepreneurial } \\
\text { Intention. }\end{array}$ & -0.02 & 0.14 & 0.89 & Unsupported \\
\hline $\begin{array}{l}\mathrm{H}_{7}: \text { Risk Taking has a significant } \\
\text { impact on Entrepreneurial Intention. }\end{array}$ & 0.25 & 2.99 & 0.00 & Supported \\
\hline $\begin{array}{l}\mathrm{H}_{8}: \text { Power Distance moderate the } \\
\text { significant impact of Risk Taking on } \\
\text { Entrepreneurial Intention. }\end{array}$ & 0.01 & 0.04 & 0.96 & Unsupported \\
\hline $\begin{array}{l}\mathrm{H}_{9}: \quad \text { Collectivism moderate the } \\
\text { significant impact of Risk Taking on } \\
\text { Entrepreneurial Intention. }\end{array}$ & 0.12 & 1.17 & 0.24 & Unsupported \\
\hline
\end{tabular}




\begin{tabular}{|c|c|c|c|c|}
\hline $\begin{array}{l}\mathrm{H}_{10} \text { : Uncertainty Avoidance } \\
\text { moderate the significant impact of } \\
\text { Risk Taking on Entrepreneurial } \\
\text { Intention. }\end{array}$ & -0.17 & 1.56 & 0.12 & Unsupported \\
\hline $\begin{array}{l}\mathrm{H}_{11} \text { : Masculinity moderate the } \\
\text { significant impact of Risk Taking on } \\
\text { Entrepreneurial Intention. }\end{array}$ & 0.14 & 1.56 & 0.12 & Unsupported \\
\hline $\begin{array}{l}\mathrm{H}_{12} \text { : Long Term Orientation } \\
\text { moderate the significant impact of } \\
\text { Risk Taking on Entrepreneurial } \\
\text { Intention. }\end{array}$ & -0.22 & 1.91 & 0.06 & Unsupported \\
\hline $\begin{array}{l}\mathrm{H}_{13} \text { : Pro-Activeness has a significant } \\
\text { impact on Entrepreneurial Intention. }\end{array}$ & 0.35 & 3.79 & 0.00 & Supported \\
\hline $\begin{array}{l}\mathrm{H}_{14} \text { : Power Distance moderate the } \\
\text { significant impact of Pro-Activeness } \\
\text { on Entrepreneurial Intention. }\end{array}$ & -0.04 & 0.28 & 0.78 & Unsupported \\
\hline $\begin{array}{l}\mathrm{H}_{15}: \text { Collectivism moderate the } \\
\text { significant impact of Pro-Activeness } \\
\text { on Entrepreneurial Intention. }\end{array}$ & -0.34 & 2.63 & 0.01 & Supported \\
\hline $\begin{array}{l}\mathrm{H}_{16}: \text { Uncertainty Avoidance } \\
\text { moderate the significant impact of } \\
\text { Pro-Activeness on Entrepreneurial } \\
\text { Intention. }\end{array}$ & 0.43 & 3.60 & 0.00 & Supported \\
\hline $\begin{array}{l}\mathrm{H}_{17}: \text { Masculinity moderate the } \\
\text { significant impact of Pro-Activeness } \\
\text { on Entrepreneurial Intention. }\end{array}$ & -0.24 & 2.60 & 0.01 & Supported \\
\hline $\begin{array}{l}\mathrm{H}_{18} \text { : Long Term Orientation } \\
\text { moderate the significant impact of } \\
\text { Pro-Activeness on Entrepreneurial } \\
\text { Intention. }\end{array}$ & 0.27 & 2.10 & 0.04 & Supported \\
\hline $\begin{array}{l}\mathrm{H}_{19}: \text { Power Distance has a } \\
\text { significant impact on Entrepreneurial } \\
\text { Intention. }\end{array}$ & -0.08 & 1.04 & 0.30 & Unsupported \\
\hline $\begin{array}{l}\mathrm{H}_{20} \text { : Collectivism has a significant } \\
\text { impact on Entrepreneurial Intention. }\end{array}$ & -0.10 & 1.34 & 0.18 & Unsupported \\
\hline $\begin{array}{l}\mathrm{H}_{21} \text { : Uncertainty Avoidance has a } \\
\text { significant impact on Entrepreneurial }\end{array}$ & 0.15 & 1.75 & 0.08 & Unsupported \\
\hline
\end{tabular}




\begin{tabular}{|l|l|l|l|l|}
\hline Intention. & & & & \\
\hline $\begin{array}{l}\mathrm{H}_{22}: \text { Masculinity has a significant } \\
\text { impact on Entrepreneurial Intention. }\end{array}$ & -0.06 & 0.76 & 0.45 & Unsupported \\
\hline $\begin{array}{l}\mathrm{H}_{23}: \text { Long Term Orientation has a } \\
\text { significant impact on Entrepreneurial } \\
\text { Intention. }\end{array}$ & 0.06 & 0.74 & 0.46 & Unsupported \\
\hline $\begin{array}{l}\mathrm{H}_{24}: \text { Gender has a significant impact } \\
\text { on Entrepreneurial Intention. }\end{array}$ & -0.35 & 7.87 & 0.00 & Supported \\
\hline $\begin{array}{l}\mathrm{H}_{25}: \text { Age has a significant impact on } \\
\text { Entrepreneurial Intention. }\end{array}$ & 0.09 & 2.28 & 0.02 & Supported \\
\hline $\begin{array}{l}\mathrm{H}_{26}: \text { Education has a significant } \\
\text { impact on Entrepreneurial Intention. }\end{array}$ & 0.14 & 2.63 & 0.01 & Supported \\
\hline
\end{tabular}

Above table shows the consequences of hypotheses, the factors having relationship is certain as the t-value $>1.96$ (for 2-tailed) which is equivalent to $\mathrm{p}<0.05$ positive effect on entrepreneurial intention. The t-values shows up there is a colossal contrast among the components and relationship has not been rejected and supported the alternative hypothesis as rendered by the $\mathrm{P}$ values.

From our hypothesis results and considering t-value and p-value, it can be said that innovativeness is the main element of entrepreneurship which has not a significant impact in entrepreneurial intention, without any moderating effect of cultural measurements. Though, risk taking and pro-activeness demonstrates a significant impact on entrepreneurial intention (EI), without any moderating effect of cultural measurements.

Just uncertainty avoidance and masculinity moderate the significant impact of innovativeness on EI. But other cultural measurements like power distance, collectivism and long term orientation does not moderate the significant impact of innovativeness on EI. For risk taking another component of EI, all the cultural measurements do not moderate the significant impact of risk taking on EI. Though, for pro-activeness, just power distance does not moderate the significant impact while other cultural measurements like collectivism, uncertainty avoidance, masculinity, long term orientation moderate the significant impact of pro-activeness on EI.

Every cultural dimension like power distance, collectivism, uncertainty avoidance, masculinity and long term orientation do not have significant impact on entrepreneurial intention in Pakistan. Other than that gender, age and education significantly affect entrepreneurial intention.

\section{Discussions}

As per the outcomes in the wake of leading a study and tests, it has been seen that innovativeness has no critical effect on entrepreneurial intention (Prasad, Ehrhardt, Liu, \& Tiwari, 2015) as that contradict previous studies (Lumpkin \& Dess, 1996), no contrasts found 
that contradicts (Subotic, Maric, Mitrovic, \& Mesko, 2018) and (Baker \& Sinkula, 2009), while having a moderating impact of power distance, long term orientation and collectivism. $\mathrm{Be}$ that as it may, on the opposite side, innovativeness has a significant effect on entrepreneurial intention if moderating impact of masculinity ( $\mathrm{t}$-value $=3.20, \mathrm{p}$-value $=0.01$ ) and uncertainty avoidance ( $\mathrm{t}$-value $=4.778, \mathrm{p}$-value $=0.000$ ) have been connected, having a $\mathrm{t}$ value of greater than 1.96 and $p$ value less than 0.05 . Yet, with no moderating impact of cultural dimensions, innovativeness likewise does not significantly affect entrepreneurial intention too. This is a direct result of the reason that the contemplated culture does not accept development for beginning their business or might be a direct result of some other factor. Discovered that the worry of individual is not the assent of group of actors, this study added the concept of innovative entrepreneurs that was mislaid in (Sandberg, Hurmerinta, \& Zettinig, 2013).

In the wake of looking at the effect of risk-taking on entrepreneurial intention it has been seen that with no moderating impact of cultural dimensions that contradicts (Richter, et al., 2016). Risk-taking $(\mathrm{t}$-value $=2.986, \mathrm{p}$-value $=0.003)$ significantly affects entrepreneurial intention having a t-value greater than 1.96 and p-value under 0.05 (Marina, Paul, Harry, \& Vladimir, 2013). Yet, in the event that we connected moderating impacts of cultural dimensions on risk-taking, at that point, it has been seen that power distance, collectivism, uncertainty avoidance, masculinity, and long term orientation has no significant effect on entrepreneurial intention that contradicts the study about women that they are very little associated entrepreneurial exercises as contrast with men (Zeffane, 2015). In this way, we can say that their way of life does not enable them to go out on a limb and get associated with their own business and they rely upon other to go out on a limb and give them the occupations. While, risk impact the gendered desires for consideration (Humbert \& Brindley, 2015) They are powerless in going out on a limb and because of this, it demonstrates no effect on the entrepreneurial intention of the factor risk-taking if moderating results of cultural dimensions connected.

The other predicted finding in this examination is that pro-activeness ( $\mathrm{t}$-value $=3.787$, p-value $=0.000$ ) significantly affects entrepreneurial intention, not just play moderation role (Wong, 2012) but also has a significant impact on EI, according to the results. In addition, pro-activeness alongside the moderating factors collectivism (t-value $=2.628, \mathrm{p}$-value $=$ $0.009)$, uncertainty avoidance $(\mathrm{t}$-value $=3.603$, $\mathrm{p}$-value $=0.000)$, masculinity $(\mathrm{t}$-value $=2.602$, $\mathrm{p}$-value $=0.010)$ and long term orientation ( $\mathrm{t}$-value $=2.104, \mathrm{p}$-value $=0.036)$ additionally have significant effect on entrepreneurial intention, previously not discussed by (Dickel, 2017) in detail and only discussed about environmental performance but we include cultural dimensions as well. Just the moderating impact of power distance alongside innovativeness has a no significant effect on entrepreneurial intention. Most significant cultural and environmental consequences that have not been discussed by (Kropp, Lindsay, \& Shoham, 2008), also highlighted in this study. It very well may be said that individuals have a place with Pakistani culture, have a positive connection between pro-activeness and entrepreneurial intention (Cov89).

Entrepreneurial intention is not influenced by power distance, collectivism, uncertainty 
avoidance, masculinity and long term orientation having (t-values $=1.04,1.34,1.75,0.76$ and 0.74 ) and (p-values $=0.30,0.18,0.08,0.45$ and 0.46 ) respectively, which supports (Anlesinya, Adepoju, \& Richter, 2019). Prior investigation of (Crespo, 2017), the effect of culture and EI have not been talked about, yet this examination contributes towards entrepreneurial methodology and grasp the differentiation among individuals. Each nation has distinctive culture; it changes with the idea of entrepreneurship. This investigation is likewise a worth expansion in (Richter, et al., 2016) multifaceted research on various nations. Shortcoming that we found in (Brieger \& Clercq, 2019) that they cover the data that is given by GEM just, not worked in single making country, has been pursued and defeated that shortcoming by concentrating on single nation.

Gender significantly affects Entrepreneurial intention having (t-value $=7.87$ and $p$-value $=0.00$ ) that repudiates with (Smith, Sirdeshmukh, \& Combs, 2016) who talked about that gender circuitously affects entrepreneurial intention. Age and education likewise impacts entrepreneurial intention having $(\mathrm{t}$-value $=2.28, \mathrm{p}$-value $=0.02$ and $\mathrm{t}$-value $=2.63, \mathrm{p}$-value $=0.01$ ) separately. Gender, age and education are viewed as significant determinants throughout person's life to begin a business, it might impact legitimately or in a roundabout way in various cases, it might change the elements of entrepreneurial activity (Stefanović \& Stošić, 2012).

The significance of this examination is that entrepreneurial intention research has explored structure unidimensional point of view. Like past research has often blended procedure and the results were diverse as per the culture of different nations. In any case, this examination concentrating on just a single nation unidimensional point of view and their culture. This examination features the entrepreneurial intentions and its sub-dimensions of pro-activeness, risk taking and innovativeness genuinely partitioned between the various qualities of procedure. Besides, sub-dimensions and results shift autonomously of one another.

\section{Conclusion}

Our examination supported the exploration of past investigations that cultural dimensions impact independent variable on dependent variable, it includes a lot of qualities and belief systems, numerous scholars trust that culture is a significant shaper of our identity (Tung, 2008). Our examination is situated in Pakistan and as indicated by their way of life we recognized various angles, and check their social effect on three autonomous factors which incorporate innovativeness, pro-activeness and risk-taking. We did an empirical analysis for our model and inspect the moderating impacts of culture on entrepreneurial aspiration. Other intervening factors like age, gender and education are additionally being a piece of our investigation. We additionally look at these factors and check the effect of these factors on an entrepreneurial intention. Our discoveries for this exploration is significant for the general population who need to work in Pakistani culture broadly or universally. An individual who needs to put resources into this nation will have a thought regarding the impacts of social measurements in regards to enterprising expectation. As such, innovativeness, pro-activeness and risk-taking may be critical to entrepreneurial alignment because it suggests a forward-looking perspective that is accompanied by new-venturing activity. The idea of 
acting in anticipation of future demand is an important component of entrepreneurship.

Our study contributes towards an entrepreneurial intention, regardless of whether the general population has innovativeness or not. We consider pro-activeness as an autonomous factor for the entrepreneurial intention that discloses to us that individuals are genius dynamic and risk-taking variable additionally incorporated the detailed that at what degree individuals are going for broke to begin another business or think innovatively. Examination demonstrates that on the off chance that masculinity and uncertainty avoidance respectably impact on creativity and enterprising expectation, at that point it demonstrates the positive connection between the factors, these directing elements enable people to think innovatively and it very well may be the supporting variable for imaginativeness. On the opposite side moderating elements like power distance, long term orientation, and collectivism does not enable an individual to think inventively and have an enterprising expectation.

The study demonstrates that risk-taking has a higher result on entrepreneurial aspiration with no moderating impact of cultural dimensions. In any case, every cultural dimensions' effects risk-taking conduct of an individual and demonstrates a weaker impact on enterprising expectation. Moreover, pro-activeness also has higher effect in collectivism, uncertainty avoidance, masculinity and long term orientation except power distance. For the normal national social design and culture of Pakistan, our model proposes that innovativeness and pro-activeness be the most applicable drivers of enterprising goal, though all cultural dimensions influence the risk-taking the mentality of a person.

This examination covers the recently referenced gaps; in this assessment we achieved progressively speculative set up together system that spreads outline concerning entrepreneurship. Focus more on innovativeness, risk-taking and pro-activeness by partner it in our assessment as a variable and furthermore considering job of social measurement like masculinity, power distance, uncertainty avoidance, long-term orientation and collectivism. In like manner getting longitudinal approach and utilize dynamic frameworks by considering different factors. Furthermore, incorporate various age gatherings, instruction and gender in our assessment by considering about the way of life of a people. Investigation based on future perspectives and their ramifications for other individuals. Also, spread Pakistani cultural impacts for EI in detail.

This investigation empowers increasingly simpler elucidation of the social impact on entrepreneurial goal, supportive and advantageous for the investigation of social contrasts. Empower the professionals to comprehend and oversee individuals from various societies and furthermore ought to be useful in drawing in with them successfully. Individual may improve its authority characteristics and set up top supervisory groups and sheets. Helpful for the global associations. Universal firms may comprehend the social conduct of their representatives with respect to their association, workers aim to take the proprietorship. It also gives bits of knowledge concerning the open entryways in Pakistan with both course of action makers and reinforce associations. Likewise, strong for the specialists who expect a huge activity in the economy.

Limitations for this examination is that there is a great deal of cultural models, yet in this 
investigation just (Hofstede, Dimensionalizing Cultures: The Hofstede Model in Context, 2001) conceptualization of culture has been pursued, might be there are some elective perspectives that may change the impacts. May be the results would be distinctive (Brewer \& Venaik, 2011) from this investigation, as certain speculations censure (McSweeney, 2002), (Oyserman, Coon, \& Kemmelmeier, 2002), force individuals to rethink about Hofstede cultural dimensions. Else (Hofstede, Hofstede, \& Minkov, Cultures and organizations: software of the mind: intercultural cooperation and its importance for survival, 2010) include one more measurement to be specific indulgence vs. restraint, that we have not use in this research. Moreover, this investigation concentrates just on Pakistan and culture fluctuates from nation to nation which may confine the generalizability of our findings.

\section{Acknowledgement}

All gratitude is presented to the Allah Almighty who deserves it the best. I wish that Allah may increase our knowledge with His mercy. This project would not have been possible without the support of many people. Kind acknowledgement is presented to my research supervisor, Dr. Danish Ahmed Siddiqui. He has guided me on each and every step with his outstanding professional knowledge, expertise and experience, and believed in my abilities and capabilities as he always supported me throughout the completion of my research.

\section{References}

Ahmed, T., Chandran, V., \& Klobas, J. (2017, January). Specialized entrepreneurship education: does it really matter? Fresh evidence from Pakistan. International Journal of Entrepreneurial Behavior \& Research, 23(1), 4-17. https://doi.org/10.1108/IJEBR-01-2016-0005

Anlesinya, A., Adepoju, O. A., \& Richter, U. H. (2019, July). Cultural orientation, perceived support and participation of female students in formal entrepreneurship in the sub-Saharan economy of Ghana. International Journal of Gender and Entrepreneurship. https://doi.org/10.1108/IJGE-01-2019-0018

Aycan, Z., Mendonca, M., Kanungo, R., \& Yu, K. (2000, January). Impact of Culture on Human Resource Management Practices: A 10-Country Comparison. Applied Psychology, 192-221. https://doi.org/10.1111/1464-0597.00010

Bacon, D. R., Sauer, P. L., \& Young, M. (1995). Composite Reliability in Structural Equations Modeling. Educational and Psychological Measurement. https://doi.org/10.1177/0013164495055003003

Baker, W., \& Sinkula, J. (2009). The complementary effects of market orientation and entrepreneurial orientation on profitability in small businesses. Journal of Small Business Management, 47(4), 443-464. https://doi.org/10.1111/j.1540-627X.2009.00278.x

Baron, R. M., \& David A. Kenny. (1986). 


\section{Macrothink}

International Journal of Human Resource Studies

ISSN 2162-3058 2020, Vol. 10, No. 1

Bayram, H., Nihat, \& Can, E. (2016). The Relationship between Entrepreneurship and Innovation: A Dynamic Panel Data Analysis. Eskisehir Osmangazi University Journal of Economics and Administrative Sciences, 11(3), 7-20.

Bell, R. (2018). Predicting entrepreneurial intention across the university. Emerald Insight.

Brewer, P., \& Venaik, S. (2011). Individualism-Collectivism in Hofstede and GLOBE. Journal of International Business Studies, 42(3), 436-445. https://doi.org/10.1057/jibs.2010.62

Brieger, S. A., \& Clercq, D. D. (2019). Entrepreneurs' individual-level resources and social value creation goals. International Journal of Entrepreneurial Behavior \& Research, 25(2), 193-216. https://doi.org/10.1108/IJEBR-12-2017-0503

Carmines, E. G., \& Zeller, R. A. (1979). Reliability and Validity Assessment. Quantitative Applications in the Social Sciences. https://doi.org/10.4135/9781412985642

Chen, J., Wang, L., \& Tang, N. (2014). HALF THE SKY: The Moderating Role of Cultural Collectivism in Job Turnover Among Chinese Female Workers. Journal of Business Ethics. https://doi.org/10.1007/s10551-014-2395-1

Chen, P. Y., Hayes, E., Larivière, V., \& Sugimoto, C. R. (2018). Social reference managers and their users: A survey of demographics and ideologies. PloS one, 13(7), e0198033. https://doi.org/10.1371/journal.pone.0198033

Chin, W. W. (1998). The partial least squares approach for structural equation modeling. Modern methods for business research, 295-336.

Covin, J. G., \& Wales, W. J. (2011). The Measurement of Entrepreneurial Orientation. $\begin{array}{llll}\text { Entrepreneurship Theory and } & \text { Practice, }\end{array}$ https://doi.org/10.1111/j.1540-6520.2010.00432.x

Covin, J., \& Slevin, D. (1989). Strategic management of small firms in hostile and benign $\begin{array}{lllll}\text { environments. } \quad \text { Strategic } & \text { Management }\end{array}$ https://doi.org/10.1002/smj.4250100107

Crespo, N. F. (2017). Cross-cultural differences in the entrepreneurial activity of men and women: a fuzzy-set approach. Gender in Management, 32(4), 281-299. https://doi.org/10.1108/GM-03-2016-0072

Cronbach, \& Shavelson. (2004). My Current Thoughts on Coefficient Alpha and Successor Procedures. Educational and Psychological Measurement, 391-418. https://doi.org/10.1177/0013164404266386

Danish, R. Q., Asghar, J., Ahmad, Z., \& Ali, H. F. (2019). Factors affecting "entrepreneurial culture": the mediating role of creativity. Journal of Innovation and Entrepreneurship. https://doi.org/10.1186/s13731-019-0108-9 


\section{Macrothink}

International Journal of Human Resource Studies ISSN 2162-3058 2020, Vol. 10, No. 1

Dickel, P. (2017, February). The Impact of Protectability and Proactiveness on the Environmental Performance of New. Corporate Governance, 117-133. https://doi.org/10.1108/CG-03-2016-0055

Dorfman, P. W., \& Howell, J. P. (1988). Dimension of national culture and effective leadership patterns: Hofstede revisited. (1, Ed.) JAI.

Earley, P., Erez, M., \& Bhagat, R. S. (1995, September). Culture, Self-Identity, and Work. Administrative Science Quarterly, 40. https://doi.org/10.2307/2393801

Fornell, C., \& Larker, D. F. (1981). Evaluating Structural Equation Models with Unobservable Variables and Measurement Error. Journal of Marketing Research, 18(1), 39-50. https://doi.org/10.1177/002224378101800104

Franke, G., \& Sarstedt, M. (2019). Heuristics versus statistics in discriminant validity testing: a comparison of four procedures. https://doi.org/10.1108/IntR-12-2017-0515

Friedman, D., \& Honzik, R. (2016). Definability of Satisfaction in Outer Models. The Journal of Symbolic Logic, 81(3), 1047-1068.

Genever, H. (2017, February). Why Risk-Takers Are Winners (and Why All Entrepreneurs Should Take Risks). Retrieved from https://www.liveplan.com/blog/why-risk-takers-are-winners-and-why-all-entrepreneurs-shoul d-take-risks/

Hair, J. (2009). Multivariate data analysis. https://doi.org/10.1017/js1.2016.33

Hair, J. F., Matthews, L. M., Matthews, R. M., \& Sarstedt, M. (2017). PLS-SEM or CB-SEM: updated guidelines on which method to use. Int. J. Multivariate Data Analysis, 107-123. https://doi.org/10.1504/IJMDA.2017.10008574

Hamid, M. R., Sami, W., \& Sidek, M. H. (2017). Discriminant Validity Assessment. Journal of Physics. https://doi.org/10.1088/1742-6596/890/1/012163

Hayes, A. F. (2013). Introduction to Mediation, Moderation, and Conditional Process Analysis: A Regression-Based Approach. Journal of Educational Measurement, 335-337. Retrieved from https://onlinelibrary.wiley.com/doi/pdf/10.1111/jedm.12050

Hindle, K. (2009). The relationship between innovation and entrepreneurship: easy definition, hard policy. Regional Frontiers of Entrepreneurship Research, 75-91.

Hofstede, G. (2001). Dimensionalizing Cultures: The Hofstede Model in Context. Online Readings in Psychology and Culture. Retrieved from https://scholarworks.gvsu.edu/cgi/viewcontent.cgi?article=1014\&context=orpc

Hofstede, G., Hofstede, G. J., \& Minkov, M. (2010). Cultures and organizations: software of the mind: intercultural cooperation and its importance for survival (3rd ed.). New York: McGraw-Hill. 
Humbert, A. L., \& Brindley, C. (2015, March). Challenging the concept of risk in relation to women's entrepreneurship. Gender in Management, 30(1), 2-25. https://doi.org/10.1108/GM-10-2013-0120

Joseph F. Hair, J., Black, W. C., Babin, B. J., \& Anderson, R. E. (2010). Multivariate Data Analysis.

Karimi, S., Biemans, H., Lans, T., \& Chizari, M., Mulder, \& Martin. (2016). The Impact of Entrepreneurship Education: A Study of Iranian Students' Entrepreneurial Intentions and Opportunity Identification. Journal of Small Business Management. https://doi.org/10.1111/jsbm.12137

Kerr, S. P., Kerr, W. R., \& Xu, T. (2017, November). Personality Traits of Entrepreneurs: A Review of Recent Literature. https://doi.org/10.3386/w24097

Kremer, Zappe, G., \& \& Sarah. (2006). A project-based approach to entrepreneurial leadership education. Technovation, 195-210. https://doi.org/10.1016/j.technovation.2004.10.012

Kropp, F., Lindsay, N. J., \& Shoham, A. (2008, March). Entrepreneurial orientation and international entrepreneurial business venture startup. International Journal of $\begin{array}{llll}\text { Entrepreneurial Behavior } \quad \& \quad \text { Research, } & \text { 102-117. }\end{array}$ https://doi.org/10.1108/13552550810863080

Kuratko, D. F. (2007). Entrepreneurial Leadership in the 21st Century. Journal of Leadership and Organizational Studies, 13(4). https://doi.org/10.1177/10717919070130040201

Linton, G. (2019). Innovativeness, risk-taking and pro-activeness in startups: a case study and conceptual development. Journal of Global Entrepreneurship Research, 9(20). https://doi.org/10.1186/s40497-019-0147-5

Linton, G. (2019). Innovativeness, risk-taking, and proactiveness in startups: a case study and conceptual development. Journal of Global Entrepreneurship Research, 1-21. https://doi.org/10.1186/s40497-019-0147-5

Lumpkin, G., \& Dess, G. (1996). Clarifying the entrepreneurial orientation construct and linking it to performance. The Academy of Management Review, 21, 135-172. https://doi.org/10.5465/amr.1996.9602161568

Macko, A., \& Tyszka, T. (2009, July). Entrepreneurship and Risk Taking. Applied Psychology, 58(3), 469-487. https://doi.org/10.1111/j.1464-0597.2009.00402.x

Malebana, M. J. (2014). Entrepreneurial Intentions and Entrepreneurial Motivation of South African Rural University Students. Journal of Economics and Behavioral Studies, 709-726.

Marina, Z. S., Paul, W., Harry, M., \& Vladimir, N. P. (2013). Entrepreneurial assets and mindsets. Education + Training, 55, 748-762. https://doi.org/10.1108/ET-06-2013-0075

Maritz, A., \& Donovan, J. D. (2015). Entrepreneurship and Innovation. Education and Training, 74-87. https://doi.org/10.1108/ET-02-2013-0018 
McSweeney, B. (2002). Hofstede's Model of National Cultural Differences and their Consequences: A Triumph of Faith - a Failure of Analysis. Human Relations, 55(1), 89-118. https://doi.org/10.1177/0018726702551004

Merriam-Webster. (1991). Webster's ninth new collegiate dictionary. U.S.A: Springfield, Mass.

Miller, D. (1983). The correlates of entrepreneurship in three types of firms. Springer, 53-76. https://doi.org/10.1287/mnsc.29.7.770

Miller, D. (1983). The Emergence of the Entrepreneurial Orientation (EO) Construct. Foundational Research in Entrepreneurship Studies, 53-76. https://doi.org/10.1007/978-3-319-73528-3_4

Mitchell, R. K., Smith, J. A., Morse, E. W., Seawright, K., Peredo, A. M., \& McKenzie, B. (2002). Are entrepreneurial cognitions universal? Assessing entrepreneurial cognitions across cultures. Entrepreneurship Theory and Practice, 9-32. https://doi.org/10.1177/104225870202600402

Muhammad, N., Ullah, F., \& Warren, L. (2016). An institutional perspective on entrepreneurship in a conflict environment. International Journal of Entrepreneurial Behavior \& Research, 22(5), 698-717. https://doi.org/10.1108/IJEBR-04-2016-0112

Ndubisi, N. O., \& Iftikhar, K. (2012, October). Relationship between entrepreneurship, innovation and performance. Journal of Research in Marketing and Entrepreneurship, 14(2), 214-236. https://doi.org/10.1108/14715201211271429

Niehaves, B., \& Ortbach, K. (2016). The inner and tha outer model in explanatory design theory: the case of designing electronic feedback systems. European Journal of Information Systems, 25(4), 303-316. https://doi.org/10.1057/ejis.2016.3

Obeidat, B., Al-Sarayrah, S., Tarhini, A., Al-Dmour, R. H., Al-Salti, Z., \& Sweis, R. (2016). Cultural Influence on Strategic Human Resource Management Practices: A Jordanian Case Study. International Business Research, 9(10), 94-114. https://doi.org/10.5539/ibr.v9n10p94

Oyserman, D., Coon, H. M., \& Kemmelmeier, M. (2002). Rethinking individualism and collectivism: Evaluation of theoretical assumptions and meta-analyses. Psychological Bulletin, 128(1), 3-72. https://doi.org/10.1037/0033-2909.128.1.3

Prabhu, V. P., McGuire, S. J., Drost, E. A., \& Kwong, K. K. (2012, August). Proactive personality and entrepreneurial intent. International Journal of Entrepreneurial Behavior \& Research, 18(5). https://doi.org/10.1108/13552551211253937

Prasad, K. V., Ehrhardt, K., Liu, Y., \& Tiwari, K. (2015). Examining the age-performance relationship for entrepreneurs: Does the innovativeness of a venture make a difference? New England Journal of Entrepreneurship, 41-57. https://doi.org/10.1108/NEJE-18-01-2015-B003 


\section{Macrothink}

International Journal of Human Resource Studies ISSN 2162-3058 2020, Vol. 10, No. 1

Prudon, P. (2015). Confirmatory factor analysis: a brief introduction and critique. Comprehensive Psychology, 4(10). https://doi.org/10.2466/03.CP.4.10

Rahim, A. W., Ismail, W. K., Thurasamy, R., \& Rahman, I. A. (2018). The Relationship of Individual Creativity with Entrepreneurial Intention via Individual Entrepreneurial Orientation (IEO). International Journal of Innovation and Business Strategy, 9(1), 41-54.

Richter, N. F., Hauff, S., Schlaegel, C., Gudergan, S., Ringle, C. M., \& Gunkel, M. (2016). Using Cultural Archetypes in Cross-cultural Management Studie. Journal of International Management, 22(1), 63-83. https://doi.org/10.1016/j.intman.2015.09.001

Sahin, F., Karadag, H., \& Tuncer, B. (2019). Big five personality traits, entrepreneurial self-efficacy and entrepreneurial intention: A configurational approach. International Journal of Entrepreneurial Behavior \& Research. https://doi.org/10.1108/IJEBR-07-2018-0466

Sajjad, S. I., Shafi, H., \& Dad, A. M. (2012). Impact of Culture on Entrepreneur Intention. Information Management and Business Review, 30-34.

Sandberg, B., Hurmerinta, L., \& Zettinig, P. (2013). Highly innovative and extremely entrepreneurial individuals: what are these rare birds made of? European Journal of Innovation Management, 227-242. https://doi.org/10.1108/14601061311324557

Sesen, H. (2013). Personality or environment? A comprehensive study on the entrepreneurial intentions of university students. Emerald Insight, 624-640. https://doi.org/10.1108/ET-05-2012-0059

Shrout, P. E., \& Bolger, N. (2002). Mediation in Experimental and Nonexperimental Studies: New Procedures and Recommendations. Psychological Methods, 422-445. https://doi.org/10.1037/1082-989X.7.4.422

Smith, R. M., Sirdeshmukh, S. R., \& Combs, G. M. (2016). Understanding Gender, Creativity, and Entrepreneurial Intentions. Education + Training, 58 Issue: 3, 263-282. https://doi.org/10.1108/ET-06-2015-0044

Stefanović, S., \& Stošić, D. (2012). AGE AND EDUCATION AS DETERMINANTS OF ENTREPRENEURSHIP. Economics and Organization, 9(3), 327-339.

Subotic, M., Maric, M., Mitrovic, S., \& Mesko, M. (2018). Differences between adaptors and innovators in the context of entrepreneurial potential dimensions. Kybernetes, 1363-1377. https://doi.org/10.1108/K-05-2017-0183

Taras, V., L.Kirkman, B., \& Steel, P. (2010). Examining the Impact of Culture's Consequences: A Three-Decade, Multilevel, Meta-Analytic Review of Hofstede's Cultural Value Dimensions. Journal of Applied Psychology, 405-439. https://doi.org/10.1037/a0018938

Thurik, R., \& Dejardin, M. (2011). The Impact of Culture on Entrepreneurship. The European Business Review, 57-59. 


\section{Macrothink}

International Journal of Human Resource Studies

ISSN 2162-3058 2020, Vol. 10, No. 1

Tipu, S. A. (2017). Entrepreneurial risk taking: themes from the literature and pointers for future research. International Journal of Organizational Analysis, 25(3), 432-455. https://doi.org/10.1108/IJOA-08-2015-0898

Tredgold, G. (2018, March). Innovation Is the Key to Entrepreneurship. Retrieved from www.inc.com/gordon-tredgold/innovation-is-key-to-entrepreneurship.html

Tukur, D. M., \& Adam, S. I. (2017, July). Culture and Entrepreneurship: An Overview of Hofstede's Cultural Dimensions. Journal of Economics and Finance, 2(7), 17-21.

Tung, R. L. (2008). The Cross-Cultural Research Imperative: The Need to Balance Cross-National and Intra-National Diversity. Journal of International Business Studies, 39, 41-46. https://doi.org/10.1057/palgrave.jibs.8400331

Weerawardena, J., \& Mort, G. M. (2006). Investigating Social Entrepreneurship: A Multidimensional Model. Journal of World Business, 41, 21-35. https://doi.org/10.1016/j.jwb.2005.09.001

Wennberg, K., Pathak, S., \& Autio, E. (2013). How culture moulds the effects of self-efficacy and fear of failure on entrepreneurship. Entrepreneurship and Regional Development, 9-10. https://doi.org/10.1080/08985626.2013.862975

Wong, S. K. (2012, September). The influences of entrepreneurial orientation on product advantage and new product success. Journal of Chinese Entrepreneurship, 4(3), 243-262. https://doi.org/10.1108/17561391211262175

Wu, W., Wang, H., Zheng, C., \& Wu, Y. J. (2019). Effect of Narcissism, Psychopathy, and Machiavellianism on Entrepreneurial Intention-The Mediating of Entrepreneurial Self-Efficacy. Frontiers in Psychology. https://doi.org/10.3389/fpsyg.2019.00360

Zeffane, R. (2015). Gender, trust and risk-taking: a literature review and proposed research model. Journal of Enterprising Communities: People and Places in the Global Economy, 221-232. https://doi.org/10.1108/JEC-03-2014-0004

Zhao, D., \& Smallbone, D. (2017, December). What affects nascent entrepreneurs' proactiveness. Asia Pacific Management Review.

\section{Copyright Disclaimer}

Copyright for this article is retained by the author(s), with first publication rights granted to the journal.

This is an open-access article distributed under the terms and conditions of the Creative Commons Attribution license (http://creativecommons.org/licenses/by/4.0/). 